Review

\title{
Conceptual Design of Micro-Bioreactors and Organ-on-Chips for Studies of Cell Cultures
}

\author{
Carl-Fredrik Mandenius
}

Division of Biotechnology, IFM, Linköping University, 58183 Linköping, Sweden; cfm@ifm.liu.se; Tel.: +46-13-28-8967

Received: 9 June 2018; Accepted: 14 July 2018; Published: 19 July 2018

\begin{abstract}
Engineering design of microbioreactors (MBRs) and organ-on-chip (OoC) devices can take advantage of established design science theory, in which systematic evaluation of functional concepts and user requirements are analyzed. This is commonly referred to as a conceptual design. This review article compares how common conceptual design principles are applicable to MBR and OoC devices. The complexity of this design, which is exemplified by MBRs for scaled-down cell cultures in bioprocess development and drug testing in OoCs for heart and eye, is discussed and compared with previous design solutions of MBRs and OoCs, from the perspective of how similarities in understanding design from functionality and user purpose perspectives can more efficiently be exploited. The review can serve as a guideline and help the future design of MBR and OoC devices for cell culture studies.
\end{abstract}

Keywords: biomechatronic design; bioprocess development; toxicity testing; in vitro assay; drug testing; heart-on-a-chip; eye-on-a-chip

\section{Introduction}

The engineering design of micro-bioreactors (MBRs) and Organ-on-Chips (OoCs) has attracted much attention in recent years [1-7]. The two terms, MBR and OoC, have diverse origins. The MBR derives its name from the bioengineering methodology of performing biological reactions in micro-scale reactor devices; OoC refers to the recreation of organs and tissues from the human body on or in a miniaturized device with a smaller volume than the original organ and with body-like fluids streaming around the cells in an in vivo-like fashion [8-10]. Despite this difference, many of the basic engineering principles coincide in the design of MBRs and OoCs. Probably due to that, the terms are used concurrently.

The kind of problems addressed with MBRs and OoCs are related. For bioprocess development, the MBRs are considered valuable tools for accelerating development of new bioprocesses with microorganisms or mammalian cells as production organisms [11,12]. The culture of the manufacturing process is scaled-down to $1-10 \mathrm{~mL}$ volume of the MBR, and critical process parameters and media composition are systematically optimized $[13,14]$. The MBRs for bioprocess development have even been scaled down to the size of chips (Bioreactor-on-a-Chip) [15] and used for mimicking chemostat or turbidostat bioreactors with bacteria and yeast [15-18]. The increased yield and productivity of the large-scale process can be reached at a much earlier stage in the process development with this approach. Commercial MBRs with >100 parallel MBR units are now on the market, e.g., ambr [19] and m3p systems [20].

With OoC devices, the aim is to facilitate the study of organ cell assemblies in vitro, under conditions that recreate in vivo conditions of the organ in the body for recapitulating time-related cellular behavior. The OoC device allows for the observation of cellular effects when exposed to drugs or other chemicals. This allows for the assessment of compounds' effects at subcellular and multicellular levels. Successfully applied, this supports the investigation of safety pharmacology 
and toxicology, and, when possible, the efficacy of drug compounds [7-10,21,22]. If OoCs generates reliable results, it will be important to control the cells' survival in the artificial milieu of small-scale OoC; their stability relates to the design of liver devices [23-25]. However, other organs [26-29] have attracted almost the same interest, e.g., pancreas, eye, cartilage, heart, and lung cells [28,29], as well as combinations of several organ cell types on the same chip [30,31]. This is of great interest, as are tumors-on-chips, which are also covered in this special issue [32,33].

Importantly, the possibility to correctly observe, monitor, and analyze the effects of the cells through imaging, sensors, and other analytical means, as well as by controlling the process in the process development MBR or OoC, are pivotal for all applications of MBRs. Miniaturized sensors, optical fibers, and imaging inside or at the outlets of the MBRs/OoCs may provide these opportunities in a reliable way [34-37]. The design of the fluidics and transport inside the reactor chamber and the mixing in the device are common design problems. This results in some very similar design solutions.

Figure 1 illuminates the similarities and diversities of MBR and OoC device for various applications. Although the intended use and outcome of the devices differ (Figure 1A), the transformations by the biological components in the devices are similar (Figure 1B). The common transformation process that occurs in every MBR device provides similar prerequisites for the design. The resulting design solutions, such as a rack of small MBR-containers with optical sensors placed at the bottom of each micro-vessel (Figure 1C); the compact artificial liver bioreactors with intertwined hollow-fibers for liquid and gas transport (Figure 1D); or small channels with an internal membrane for transepithelial electrical resistance measurement (TEER) for drug penetration studies, PDMS chips with double channels, and parallel channels (Figure 1E) are all examples that share the general structure in Figure $1 \mathrm{~B}$. Consequently, the design of the devices should follow that frame.

A Type of Needs for Micro-bioreactors and Organ chips

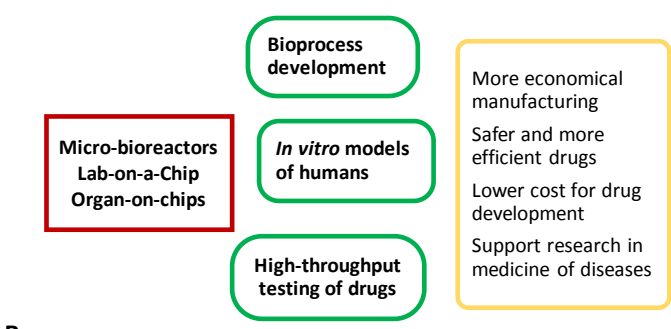

$\underline{\mathbf{B}}$

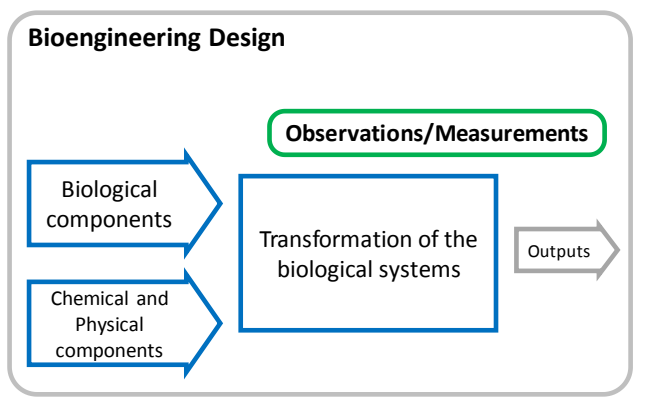

$\underline{\mathbf{C}}$

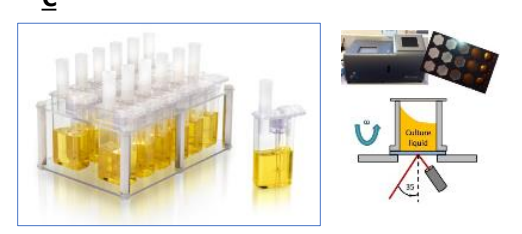

$\underline{\mathbf{D}}$

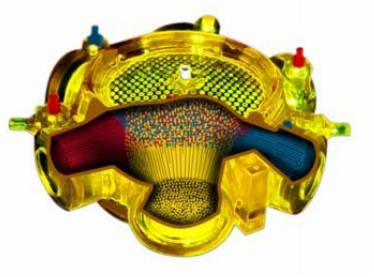

$\underline{E}$

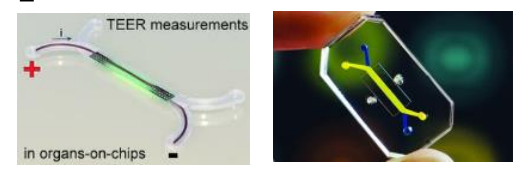

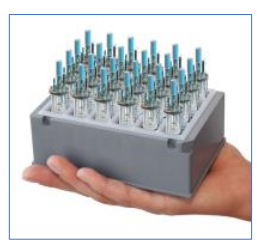
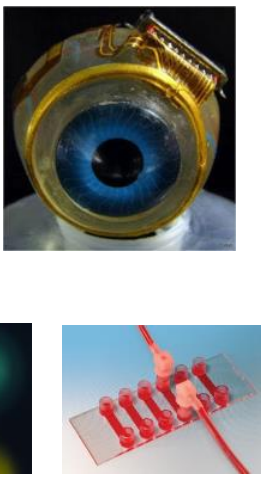

Figure 1. The similarities and diversities of micro-bioreactor design. (A) MBRs and OoCs have distinct purposes, which are expressed as user needs and requirements, e.g., the device should generate data for more economical manufacturing, safer and more efficient drugs, low cost for development, and support for medical research; (B) Despite the diversity in needs, a common transformation process can be outlined; (C) This is shared for MBRs used for process development; (D) for artificial liver bioreactors; and (E) for small plastic chips with multi-channels and internal membranes.

Thus, the engineering design of MBRs and OoCs have much in common, especially at a conceptual level. Established conceptual design methodology [38,39] could therefore significantly facilitate the development process of new MBR and OoC devices. The established conceptual design methodology 
is based on approaching the design of a new product from a functional perspective in which the functionality of the product drives the development of the design. In industrial design, conceptual methodology is widely applied to mechanical and electrical products [40]. However, in bioengineering it has been so far rarely used, with only a few examples on bioreactor scale-up [41,42], bioprocess configuration, monitoring and control $[43,44]$, and stem cell production $[45,46]$, but also recently for organ-on-chips [47].

In this review article, it is shown how the general conceptual design methodology can be applied to develop and improve the design of micro-bioreactors on a functional level. Two examples of conceptual design are shown to illuminate the similarities and differences in the design of MBR and OoC: (1) an MBR for production of hamster cells and (2) a heart-on-a-chip reactor for drug testing.

\section{Conceptual Design Methodology}

The conceptual design methodology is based on a systematic procedure to analyze the design objectives and, from these, conceive alternative design solutions that meet the objectives for a new product prototype [38-40,48]. The workflow in the development process in conceptual design starts with identifying the functions that are required to realize the user needs of the product and, from that, select and configure functional components that can effectuate user needs (Figure 2). Alternative configurations are compared with user needs and ranked versus user needs. This results in a preferred configuration. Once this choice is made, the functional components of the configuration are replaced with real physical components or objects. This results in a blueprint for an initial prototyping, which then undergoes testing and is transferred to the manufacturing of the product [30]. The methodology is well-known in mechanical engineering. It is seldom applied in bioengineering, e.g., for bioprocesses, biosensors, and organ chip device design. In the following, the general workflow in conceptual design when developing a MBR prototype is described.

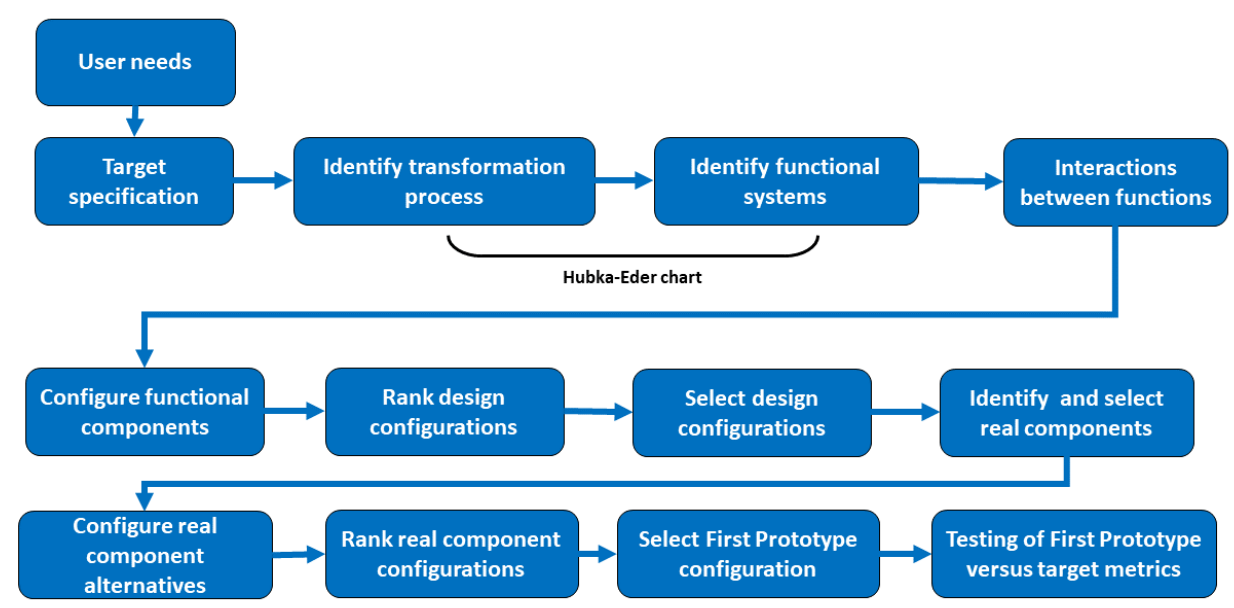

Figure 2. The workflow in conceptual design when developing a new product prototype as suggested by several authors [30-32]. The steps are iterative and partly parallel to speed up the work in the design team.

\subsection{Design Objectives, User Needs and Specification of Target Values for Design}

For achieving success with the conceptual design, a stringent and covering description of the design objective, or the design mission, is the starting point in the process of finding the appropriate design solution. The description of the objective constrains the design. Indirectly, it also encircles existing or potential users [49]. Once the users are known, they can be interrogated about their actual needs and requirements on the design solution [50]. Generally, the user needs for MBRs and OoCs vary with the purpose of the targeted product, which results in different priorities as shown in Table 1. The table elucidates the wide variation in character of needs and requirements that exist, in which some significantly impact the design, while others do not. For example, a certain number of cells are 
necessary for recapitulating an in vivo function, which sets the minimal size of the MBR-unit; critical biomarker molecules (or protein product, side-products) are produced in amounts possible to measure, which sets another minimal limit for the number of cells required in the MBR-unit; distribution of oxygen and uptake of oxygen in the unit may also be requirements that constrain the design.

Table 1. Examples of common user needs of micro-bioreactors and organ-on-chips.

\begin{tabular}{|c|c|c|}
\hline Users' Needs and Requirements & Rationales or Examples & Priority \\
\hline $\begin{array}{l}\text { Maintain human organ cells with number of a } \\
\text { corresponding human organ equivalents }\end{array}$ & $\begin{array}{l}\text { Lower number of cells in a reactor unit } \\
\text { would not show relevant data }\end{array}$ & 10 \\
\hline $\begin{array}{l}\text { Cells shall maintain the same functionality } \\
\text { in vitro as they do in vivo }\end{array}$ & $\begin{array}{l}\text { In most assays, the functionality is the } \\
\text { target end-point to be observed }\end{array}$ & 10 \\
\hline $\begin{array}{l}\text { A multi-cellular system should be } \\
\text { recapitulated in the MBR/OoC }\end{array}$ & $\begin{array}{l}\text { A human organ or tissue is in vivo, like } \\
\text { if it interacts with adjacent cells }\end{array}$ & 9 \\
\hline $\begin{array}{l}\text { Excreted metabolites shall be analysed in situ } \\
\text { or at line with sensitive analytical means }\end{array}$ & $\begin{array}{l}\text { Amounts of analytes produced in the } \\
\text { MBR are minutes due to scale }\end{array}$ & 9 \\
\hline $\begin{array}{l}\text { Cell densities equivalent to an industrial } \\
\text { production system }\end{array}$ & $\begin{array}{l}\text { In-process development should have } \\
\text { cell concentrations on a large scale }\end{array}$ & 8 \\
\hline $\begin{array}{l}\text { Material properties of MBR should not } \\
\text { interfere with the biological transformation }\end{array}$ & $\begin{array}{l}\text { Some materials are toxic, absorb drugs, } \\
\text { or affect gradients of gases }\end{array}$ & 8 \\
\hline $\begin{array}{l}\text { Microfluidic conditions in the device should } \\
\text { not harm the cells capacity }\end{array}$ & $\begin{array}{l}\text { Shear force in the micro-reactor shall not } \\
\text { change cells functional behaviour }\end{array}$ & 7 \\
\hline $\begin{array}{l}\text { The MBR/OoC shall be operable with stable } \\
\text { performance over extended time periods }\end{array}$ & $\begin{array}{l}\text { Short-term acute effects }(<1 \text { day) are of } \\
\text { lesser value than chronic ( }>14 \text { days) }\end{array}$ & 7 \\
\hline $\begin{array}{l}\text { Compounds should be exposed to cells or cell } \\
\text { organoids in a relevant way }\end{array}$ & $\begin{array}{l}\text { Diffusion, shear, and gradients in MBR } \\
\text { should reproduce in vivo perfusion }\end{array}$ & 6 \\
\hline Allow controlled addition of media factors & The exposure of factors & 2 \\
\hline $\begin{array}{l}\text { Gradients in the MBR of } \mathrm{O}_{2}, \mathrm{CO}_{2} \text {, pressure, } \\
\text { and temperature should be in vivo-like }\end{array}$ & $\begin{array}{l}\text { Variations in gradients are known to } \\
\text { influence cellular response }\end{array}$ & 1 \\
\hline
\end{tabular}

Other more specified user needs for an MBR related to the design objective could, for example, involve longevity of use of the MBR, generation of gradients in $\mathrm{pO}_{2}$ and nutrients in the device, transformation rates of the cell culture, scalability of units, and flow-through rates. Such needs are highlighted by other authors in this special issue, e.g., by Wrzesinski \& Fey [24] on oxygen supply to liver cells in an MBR, by Freyer et al. [23] on 3D microstructure of liver cell MBRs, and by Fernandez et al. [37] on oxygen measurement in MBRs.

Once needs are identified and clearly described, they are also specified with target values or range of values. The target metrics may vary considerably. Table 2 gives examples for a liver-on-a-chip [47]. Note that specified values can be either quantitative or qualitative.

Table 2. User needs of a micro-bioreactor with organ cells.

\begin{tabular}{ccc}
\hline User Needs & Target Metrics (Examples) & Specification (Examples) \\
\hline MBR shall have multi-cellular systems & At least three cell types & Hepatocytes, Kupfer cells, fibroblast \\
Cells shall have in vivo-like functionality & Cells per MBR unit & $50,000-75,000$ cells \\
Cells as in human organ equivalent & Cells in equivalent & 25,000 cells \\
Extracellular matrix & Hydrogel type & Matrigel or RGD-PEG \\
Flow of nutrients & Shear force number & \\
Measurement be extended time periods & Days & $>10$ days \\
Controlled addition of growth factors & Pump rates & $\pm 10 \mathrm{~nm}$ \\
Microscope In situ inspection & Microscopic resolution & 3 \\
Sampling of effluent fluid & Number sampling ports & More than $10 \%$ \\
Oxygen transfer & Dissolved oxygen tension & \\
Oxygen permeability of device material & mg O 2 per mL and hour & $25-30 \%$ \\
Material properties of device & Porosity & $1-2$ \\
Recycling of media & Recycling ratio &
\end{tabular}




\subsection{Mapping of the Functional Systems of the Transformation Process and Assessing Their Interactions}

A key activity in conceptual design is to describe and establish the structure of the transformation that the designed prototype should perform and what functions are required to perform the transformation. This is done in a graphical representation of the transformation and functions (Figure 3A), a so-called Hubka-Eder map (named after Vladimir Hubka (1924-2006) and Wolfgang Ernst Eder (1930-2017), the originators of this representation) [38]. The essential purpose of this map is (1) to define the transformation process, usually in the phases for preparation, main transformation, and finishing, that should take place in the designed device; and (2) to define the functions required for carrying out the transformation process [48]. The functions are structured into groups of systems, and these are further broken down into functional subsystems (Figure 3B). In a mathematical formalism, this can be described as

$$
R=\sum_{i=0}^{n} \times\left(\sum_{j=0}^{n} F S i, j\right)
$$

in which $F S i, j$ are the functional sub-systems. The $i$ index refers to main functional systems, which we divide into the biological systems, the technical systems, the information systems, the management systems, and the human systems necessary for carrying out the transformation process. To these systems, we also add the unknown surrounding environment, referred to as the active environment, which can influence the functions in ways we are not able to foresee. That could be biological variation, unpredictable sample background, or even influences associated with laws and regulations.

The functional systems and sub-systems interact with the transformation process to drive it forward but can also interact with adjacent functional sub-systems. Understanding the effects of these interactions on the transformation process is the core for accomplishing a functional prototype and is fundamental for making important design decisions. Figure $3 \mathrm{C}$ shows a convenient way to represent these interaction effects by ordering them into an interaction matrix, IM:

$$
I M=\left[\begin{array}{ccc}
w 1,1 F S 1,1 & \cdots & w 1, j F S 1, j \\
\vdots & \ddots & \vdots \\
w i, 1 F S i, 1 & \cdots & w i, j F S i, j
\end{array}\right]
$$

in which the functional sub-systems are represented by a position in the matrix. The weights $w i, j$ are values estimating the interaction strengths. These strengths are not precise measures and should only be seen as relative estimates for comparing each $F S i, j$.

When designing MBR devices, technical data from literature can often be helpful. The wealth of published data should, however, be carefully used and valued.

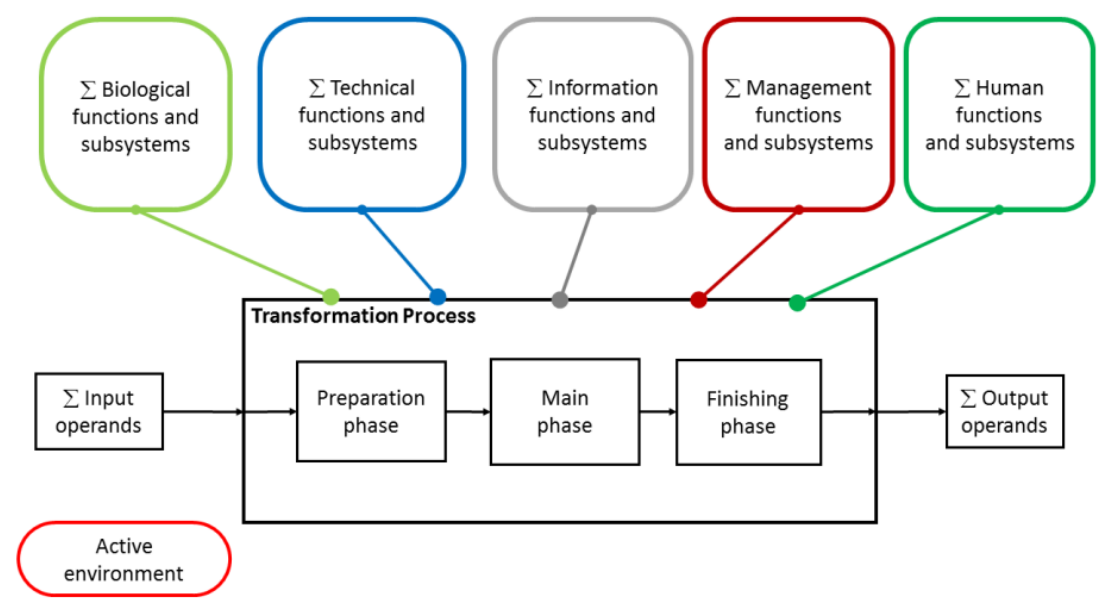

(A)

Figure 3. Cont. 


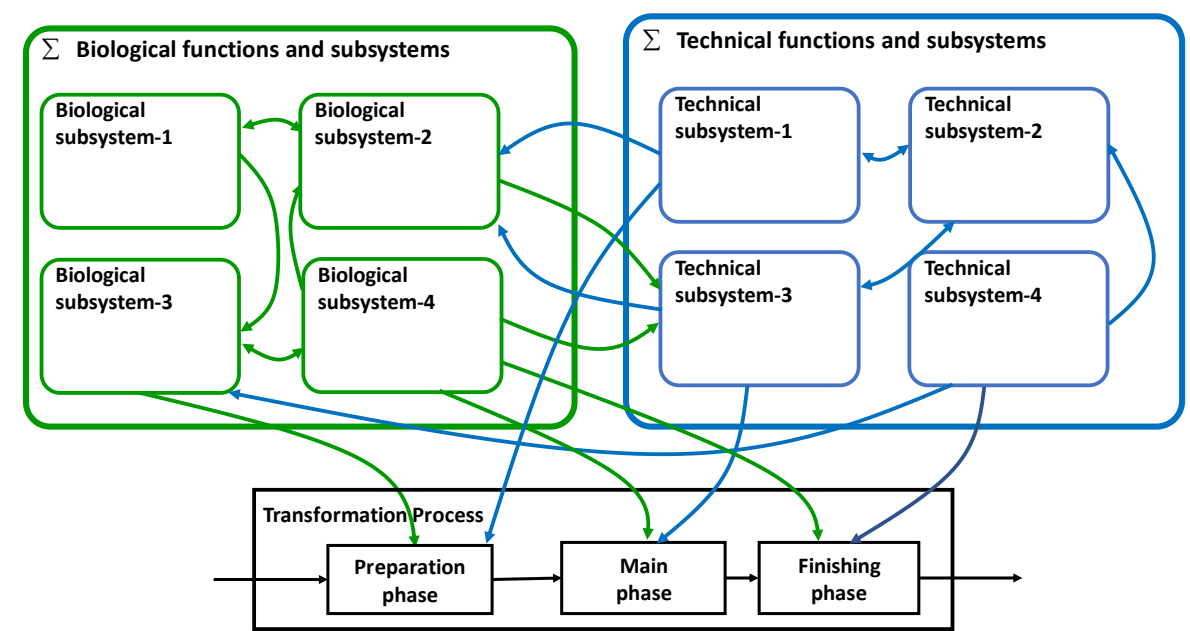

(B)

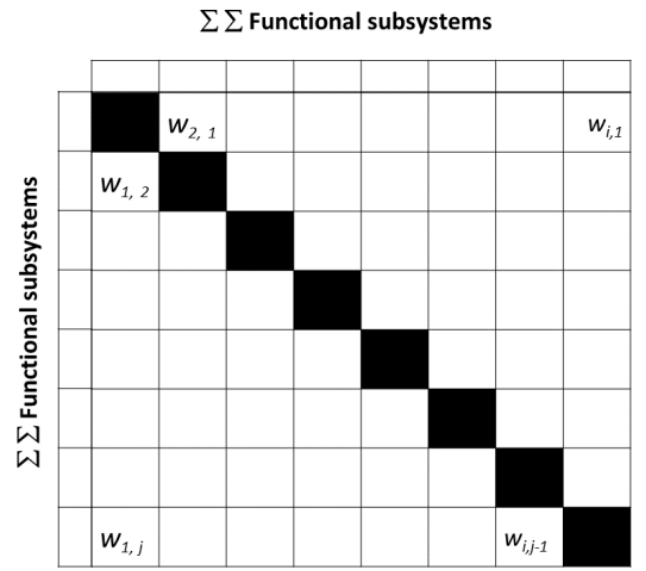

(C)

Figure 3. (A) Overall Hubka-Eder map showing the transformation process and functional systems; (B) a zoom-in of the biological and technical subsystems and their interactions in between and with the transformation process phases; and (C) the interaction matrix with assessed interaction effects between subsystems.

\subsection{Key Functional Components}

The Hubka-Eder mapping and the interaction analysis facilitate identification of essential functional components necessary for the design of the prototype [38]. Figure 4A shows a collection of 17 functional components suitable for the design of an MBR prototype, with the functional components grouped in the function systems from the HE-map. Note that a functional component is solely a conceptual object capable of carrying out the function, not a defined physical component, such as a valve or a pump. For example, a fluidic transporter only tells what you want the component to do, not if it is produced by pumping, using a syringe, or utilizing gravitational force. These "neutral", non-physical, or non-real components allow one to investigate how the functions can be configured. Figure 4B shows two examples of configurations from the 17 functional components. In one configuration (I), cells are transferred to a temperature-controlled space in which the biological systems are preserved in several separately contained and temperature-controlled units with sensor functions. In the other configuration (II), all units are placed in the same temperature-controlled unit, and sensors are shared between the contained cell units. Theoretically, the 17 functional components in Figure 4 can be combined in a multitude of configurations, most of them unrealistic, but a few are realistic and worth investigating further. 
(A) Functional components

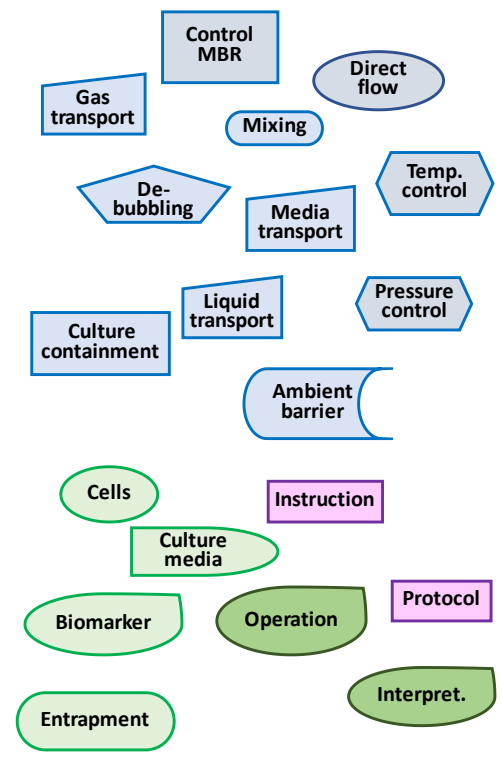

\section{(B) Configurations}

(I)
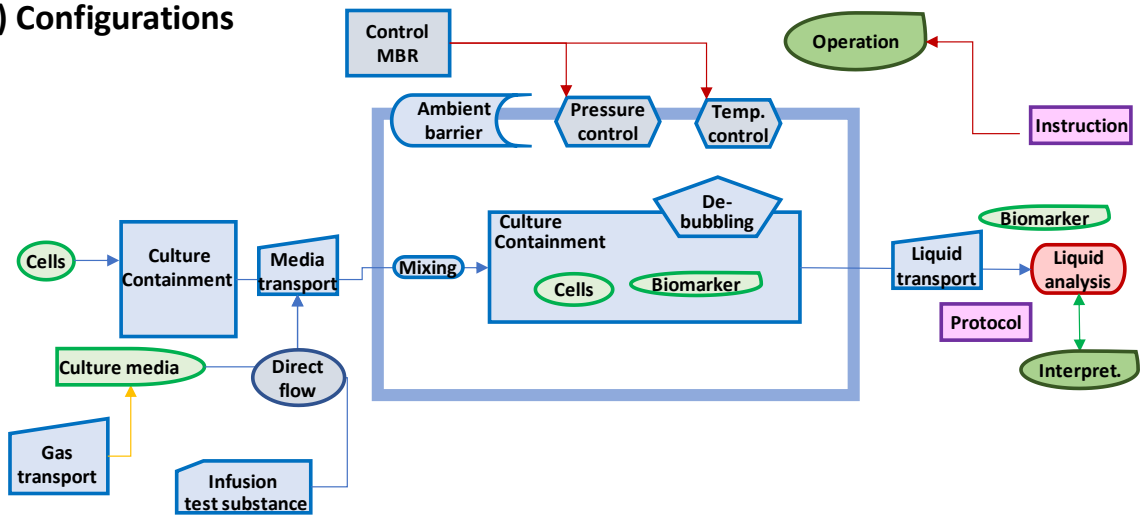

(II)

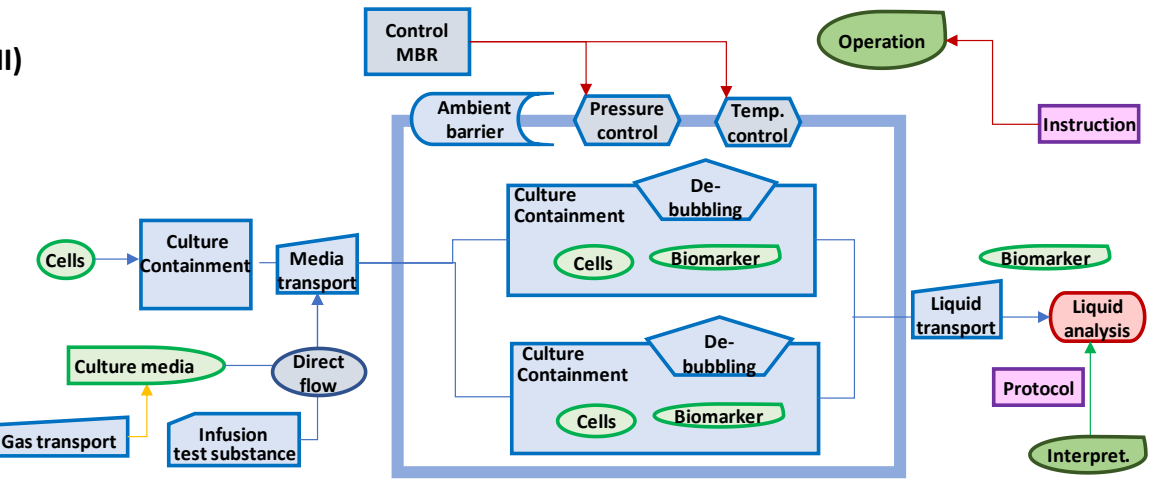

Figure 4. (A) Biological (green), technical (blue), and information (red) functional components required in an MBR device as identified from the functional subsystems in the HE-map in Figure 3; (B) Two examples of configurations from these functional components in which two MBR units are included in the prototype design.

\subsection{Assessment of Configuration Alternatives}

The configuration alternatives generated from the functional components should now be compared and assessed versus the user specification target values in Table 2 [40]. Initially, a relatively high number of configuration alternatives can be assessed by a rough screening (20-30 configurations 
depending on number of components). By that, the number of configurations can be reduced to less than 10, and these can be assessed more thoroughly. Typically, the configuration alternatives can be limited to five or six. We rank their assumed effect on the target specification value; either this is quantitative or qualitative. The ranking is at this stage relative, but could be quantified more exactly, e.g., variability, standard deviation, limit of detection, or analysis time. This will require experimental evidence, e.g., measurements in a test bench in a pre-prototype. Table 3 shows an example of estimated ranking scores for four configuration alternatives. A four-level ranking as shown in the example is sufficient to discriminate the configurations versus the specification values. In Table 3, alternative 2 gets the highest score and is chosen for further development towards a prototype. In the table it is also possible to introduce weight factors to tune the importance of each need in relation to the design objective. For example, low price may have much more impact than size. The balance of the weights is decisive for the final ranking score. A design team must consequently be aware of this and be cautious of how they treat values. However, if they do this, it will become an efficient means with which to perform sensitivity and risk analysis at this early stage of the design.

Once the functionally most feasible design alternative has been selected from the scoring of the user needs, the real physical components replace the functional components [48]. These real components are identified and chosen in a similar selection process. The real component alternatives are screened and scored versus the user needs. Thus, the columns in Table 3 represent real component alternatives that are compared versus the listed user needs and scored.

The real components can be collected from commercial vendors or be specially designed by the team. Of course, commercial components are preferred when they are available and specifications are known. The screening is done similarly and results in a preferred alternative. This alternative will then be prototyped and tested.

Table 3. Example of ranking of design alternatives versus target specification metrics ${ }^{1}$.

\begin{tabular}{|c|c|c|c|c|}
\hline Design Alternatives User Needs & Alternative 1 & Alternative 2 & Alternative 3 & Alternative 4 \\
\hline Allow co-culture of cells & $\bullet \bullet$ & $\bullet \bullet \bullet$ & $\bullet \bullet$ & $\bullet$ \\
\hline Cells have in vivo-like functionality & $\bullet \bullet$ & $\bullet \bullet \bullet$ & $\bullet$ & $\bullet$ \\
\hline Extracellular matrix possible to mimic & $\bullet \bullet$ & $\bullet \bullet \bullet$ & $\bullet \bullet$ & $\bullet \bullet$ \\
\hline Continuous flow of nutrients & $\bullet \bullet$ & $\bullet \bullet \bullet$ & $\bullet \bullet$ & $\bullet \bullet \bullet$ \\
\hline Exposure of test compounds to cells & $\bullet \bullet \bullet$ & $\bullet \bullet \bullet$ & $\bullet \bullet \bullet$ & $\bullet \bullet \bullet$ \\
\hline Allow controlled addition of growth factors & $\bullet \bullet$ & $\bullet \bullet$ & - & $\bullet \bullet$ \\
\hline In situ inspection with confocal microscope without interference & $\bullet \bullet \bullet$ & $\bullet \bullet \bullet$ & - & - \\
\hline Sampling of effluent fluid & $\bullet \bullet \bullet$ & $\bullet \bullet \bullet$ & $\bullet \bullet \bullet$ & $\bullet \bullet \bullet$ \\
\hline Material properties of device not interfering & $\bullet$ & - & $\bullet$ & $\bullet \bullet$ \\
\hline Recycling of outlet flow & $\bullet \bullet \bullet$ & $\bullet \bullet \bullet$ & - & $\bullet$ \\
\hline Total score of ranking & 32 & 37 & 28 & 28 \\
\hline
\end{tabular}

${ }^{1}$ Compliance with user needs $\bullet \bullet \bullet$ high; $\bullet \bullet$ partly possible; $\bullet$ low or uncertain; and - none or impossible.

\section{A Micro-Bioreactor for Process Development of Monoclonal Antibody Production}

The design mission in this application is to develop an MBR prototype that can be used as a tool in process development of large-scale bio-production of monoclonal antibodies [17,51-54]. One of the dominating products on today's biotechnology market is recombinant monoclonal antibodies for use as bio-therapeutics and for diagnostics. The most commonly used production organism is Chinese Hamster Ovary $(\mathrm{CHO})$ cells, but also other cells are used, such as hybridoma and HEK 
cells $[55,56]$. Before scaling-up to production, the culture conditions are thoroughly investigated in process development on a small scale [57]. This ensures that the production process is optimized with regards to cell growth rate, antibody production rate, and culture media composition; has optimal values for physiochemical parameters such as temperature, $\mathrm{pH}$, and dissolved oxygen tension in the reactor; is optimal with regard to initiation and propagation of the recombinant expression system in the CHO-cell culture; and applies feeding profiles of nutrients and other growth factors to the bioreactor [58]. In the case of monoclonal antibody production, great concern is devoted to reducing formation of variants of the IgG molecule, such as multimeric and fragmented forms or various glycosylated forms of IgGs [59]. For other bioprocesses, with other expressed proteins, similar modifications are of concern, such as oxygenated, aminated, clipped, or degraded product molecules. All these process development issues are very time-consuming tasks, but are absolutely necessary to scrutinize in the early process R\&D.

The MBRs are excellent tools for such R\&D work due to their small size and possibility for parallel testing. By using MBRs process, development can be accelerated significantly [11]. Examples of successful steps taken in this direction are emerging mini- or microscale bioreactors with online sensors for measurement of critical process parameters $[19,20]$. These scaled-downed bioreactor systems have volumes in the range 1-20 mL. Commercial systems are already on the market for suspension cell cultures with a variety of designs [24] (see also Figure 1C).

Conceptual design methodology can efficiently support the design of new MBRs for these purposes [43]. Bioprocess developers have good practical notions of the needs and requirements of MBRs for process development purposes. The most common requirements and specifications for efficient scale-downed optimization work are shown in Table 4.

Table 4. User needs of a micro-bioreactor for process development of mammalian cell cultures.

\begin{tabular}{|c|c|c|}
\hline User Needs & Target Metrics & Specification \\
\hline \multicolumn{3}{|l|}{ Biological functions } \\
\hline Mammalian cells shall be used & Cell type & CHO, HEK cells \\
\hline Concentration range of cell culture & Cell/mL & $10,000-10,000,000$ \\
\hline Expression of extracellular protein & Proteins expressed & IgGs \\
\hline Same culture media shall promote both growth and expression & Type of media to be used & Serum-free medium \\
\hline Culture time & Days & 7-14 days \\
\hline \multicolumn{3}{|l|}{ Technical functions } \\
\hline Gentle well-distributed mixing & Shaken or stirred & Shaken \\
\hline In situ inspection with confocal microscope without interference & Yes/No & Yes \\
\hline Sampling of effluent fluid & Offline/inline & Offline \\
\hline Oxygen transfer & $\mathrm{k}_{\mathrm{L}}$ a value for OTR & $>100 \mathrm{~h}^{-1}$ \\
\hline Permeability of device & Oxygen permeability (\%) & $<1 \%$ \\
\hline Material properties of device & Surface hydrophobicity (angle) & 10 degree \\
\hline \multicolumn{3}{|l|}{ Information functions } \\
\hline Online information about physical conditions in the MBR & Sensor types & Temp., $\mathrm{pH}, \mathrm{pO}_{2}$ \\
\hline Offline information about content of culture media & Analytes analyzed offline & All monomers in culture media \\
\hline Offline information about IgG forms & Analytes analyzed offline & IgG forms \\
\hline Low fabrication cost & Percentage of the sales price & $>10 \%$ \\
\hline
\end{tabular}

The table addresses the wide range of cell density or cell number required. It is critical in an MBR to have a volume that is large enough for generating statistically trustworthy data, achieving homogenous fluid in the miniaturized bioreactor system and creating gradients comparable to the scaled-up system. This demand complicates the design for transfer of gaseous molecules, in particular, for oxygen transfer from the gas bubble phase to the liquid phase at the scale of the MBR. Previous designs have either been designed as microtiter-like MBR arrays with sensors in the bottom of each bioreactor-well (e.g., Sartorius, m2p-labs) $[19,20]$ or as separate MBR units with impellers and submerged micro-sensor probes and external pumps (Ambr) [19]. Comparisons with laboratory scale bioreactors of 2-5 L show 
good correlations, thus indicting that homogeneity of the liquid in the MBR and laboratory scale reactors at this scale is the same when testing mammalian cells, which are the easier cases due their low transfer rate [60]. The table addresses conditions related to these rheological functions of the MBR, as efficiency of mixing of the fluid, transfer of oxygen, addition and withdrawal of nutrients, and sterility demands. These requirements coincide with large-scale cell culture reactors and have also previously been discussed [43].

Furthermore, the cell growth and protein expression in the cell culture in the MBR need to be monitored to provide information about the culture for optimizing conditions and procedures to be transferred to the large-scale process [61,62]. This includes online monitoring of temperature, $\mathrm{pH}$, and dissolved oxygen and offline measurements of components in the bioreactor media, such as product forms, excreted metabolites, and residual nutrients. Finally, the requirements on the MBR design should address management protocols for data analysis and operation, as well as specifications for MBR fabrication (materials, cost, and maintenance needs).

The specification of the user requirements in Table 4 suggests a Hubka-Eder map with function systems as depicted in Figure 5. The biological system functions follow from the design mission where the cell line (CHO-cells) has the prime function to express a high titer of the target product (monoclonal IgG) using a recombinant gene construct. The choice of a suitable $\mathrm{CHO}$ cell line and expression system is decisive for reaching the production goal. The composition of the culture medium is decisive for the performance of the culture in respect to growth rate, as well as product formation rate. Thus, the interactions between these subsystems, the cell line, the expression system, and the medium are critical issues for the design of the MBR.

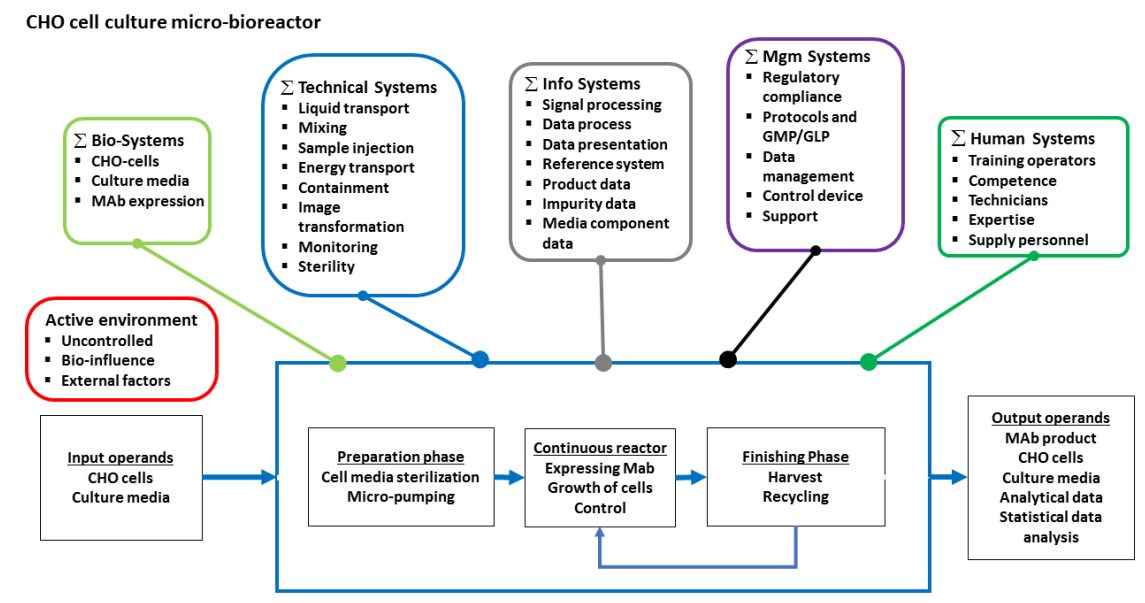

Figure 5. Hubka-Eder map showing the functional systems and subsystems in a continuous recycled MBR for bioprocess optimization of a $\mathrm{CHO}$ cell culture producing monoclonal antibody.

The technical system functions are the following: (1) to contain the miniaturized cell culture volume; (2) to provide a sterility barrier towards the environment; (3) to aerate the culture with oxygen a way that is comparable with the large-scale application; (4) to transport culture media with nutrients and excreted product(s) to and from the contained culture; and (5) to measure in real-time the physical and chemical conditions of the culture and its media [57].

The functions of the information system are to collect information from real-time measurements and offline analysis performed in the effluent from the MBR and display these data for process optimization. The information system should also provide information about the performance of the MBR itself and its control functions for temperature, $\mathrm{pH}$ and $\mathrm{pO}_{2}$, and transport systems (e.g., mixing and pumping).

The functions of the management systems are to provide protocols for MBR operation, computation methods for data analysis, and control of MBR operations through its technical systems. The human systems involved are the laboratory technicians that operates the MBR, the process 
development engineers and other experts that compute and interpret data from MBR experiments, and service and support personnel that maintain the MBR. These humans interact with all of the other systems and must be able to do that efficiently.

Also shown in the HE-map in Figure 5 is the active environment. This could, for example, be unanticipated biological variations of the performance of the cell line and expression system, partly ascribed to our lack of biological understanding of the complexity of the cell machinery of the $\mathrm{CHO}$ cells. Such influences or other influences from the surrounding environment of the MBR should be compensated for, especially by the technical subsystems based on data from the information systems.

All of the systems in the HE-map interact with each other and with the phases of the transformation process. The strengths of these interactions should be analyzed in the interaction matrix (cf., Figure 3C), and those interactions that have high impact should be singled out.

Based on this analysis, 16 functional components can be identified that need to be available when configuring the design. Figure $6 \mathrm{~A}$ shows the functional components for containment, mixing, infusion of media, real-time data sampling, and transportation. The components of the biological functions are limited to the function of the cell line to express $\operatorname{IgG}$, the gene function components, and the functions of the culture medium to enhance growth and IgG production. Information components are the information per se and the devices that can generate the information. The management components are software and instructions and rules to be followed. The humans are the individuals able to carry out the functions. These 16 components can easily be arranged in more than ten plausible and realistic configurations. Figure 6B shows two of these configurations, both close to existing MBR products $[19,20]$.

In a full design analysis at least up to 20 configurations would be arranged from the functional components. In configuration I in Figure 6B, each of the parallel MBR units is controlled separately with its own sensors and control units, although they are supervised with one management system. In configuration II, the MBR units are placed in one sensor and control unit. Importantly, the configuration diagram shows only functions for which several physical objects or devices may effectuate the functions.

Comparing these two configurations with the specification list in Table 4 results in a ranking that does not favor any of the configurations (Figure 6C). In the ranking, the weight factors for each specified need have been the same $(w=1.0)$. This may, however, not reflect the actual importance of each need. For example, if the cost is upgraded to $w=2$, which is a sound assumption, and the other need attributes are tuned down, the total score ranks makes the second configuration (II) alternative the preferred design solution.

(A) Functional components

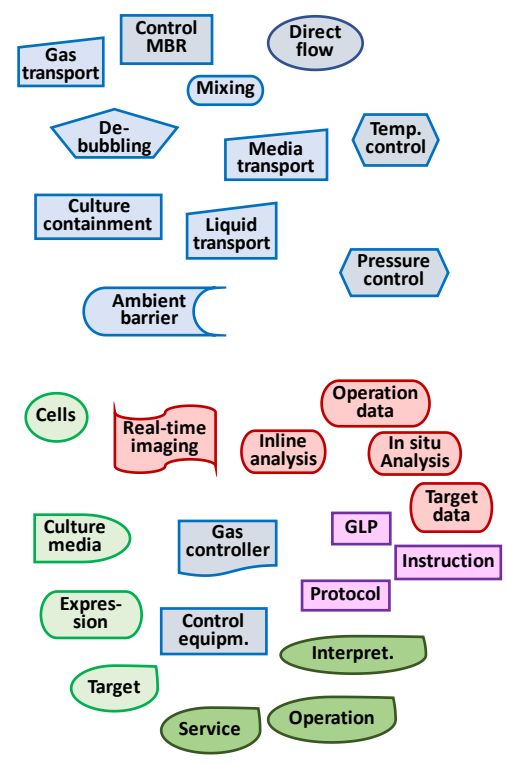

Figure 6. Cont. 


\section{(B) Configurations}

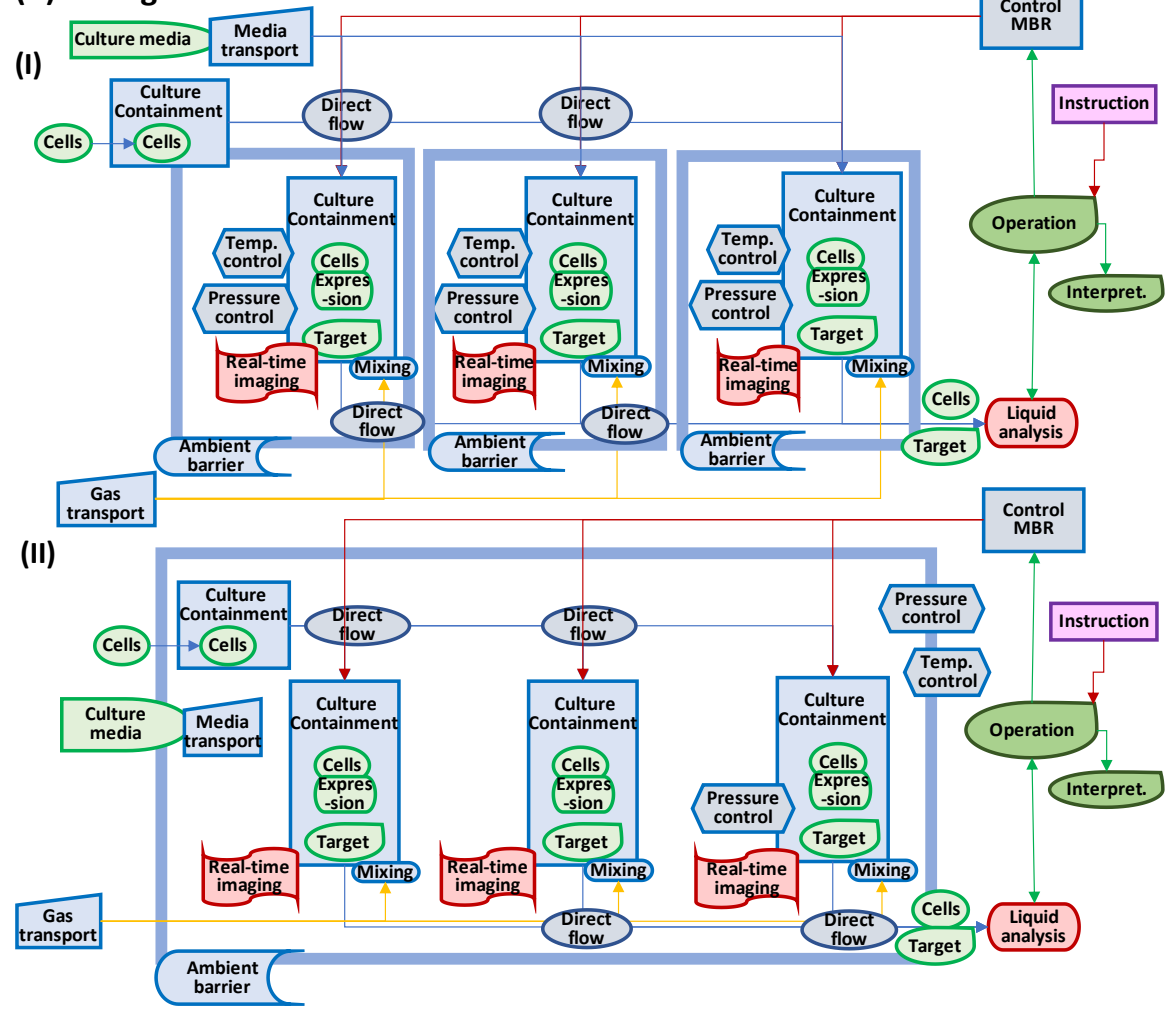

(C) Scoring of user needs (MBR in process development)

\begin{tabular}{|c|c|c|c|c|}
\hline & User needs & Configuration I & Configuration II & Weights \\
\hline 1 & MBR allows cell density of $0.110^{6}-10010^{6}$ cells $/ \mathrm{mL}$ & 4 & 4 & $50 \%$ \\
\hline 2 & MBR shall remain sterile for at least 30 days experimentation & 4 & 5 & $40 \%$ \\
\hline 3 & Chamber of MBR shall not have any gradients & 4 & 4 & $80 \%$ \\
\hline 4 & Mixing efficiency of MBR should reproduce large scale & 4 & 4 & $90 \%$ \\
\hline 5 & MBR shall allow continuous and fed-batch operation & 5 & 3 & $80 \%$ \\
\hline 6 & MBR should have as many real-time sensors as possible & 3 & 4 & $70 \%$ \\
\hline 7 & MBR shall be easy to scale-out for high-throughput tests & 3 & 5 & $60 \%$ \\
\hline 8 & MBR shall be convenient to operate for lab technicians & 4 & 4 & $40 \%$ \\
\hline \multirow[t]{3}{*}{9} & Fabrication cost of MBR shall be as low as possible & 2 & 5 & $200 \%$ \\
\hline & Score with $100 \%$ weights & 38 & 38 & \\
\hline & With weight factor as in column & 23.9 & 30.6 & \\
\hline
\end{tabular}

Figure 6. (A) Functional components for conceptual design of a MBR for bioprocess development; (B) Two configurations of these functional components; (C) Comparison and ranking of these two configurations versus user needs in Table 4 in which scores are calculated for weight factors all $100 \%$ or as in last column in the table.

In the next step of the design, the chosen conceptual design alternative is translated into a configuration with real physical components replacing the functional components. Thus, common components, such as plastic containers, micro-pumps, temperature and $\mathrm{pH}$ sensors, impellers, or robotic racks are introduced and compared. In a second ranking table, the need specifications are used again and component alternatives scored (pumps, gravity mixers, osmotic pumps, and optical and electrical sensor devices) according to their ability to meet the requirements of the specifications (see ranking Table S1 in Supplementary Information) [63-67]. With these ranked components, a first prototype is blueprinted, constructed, and tested (Figure 7). This prototype undergoes testing procedures as commonly done in all product development in the manufacturing industry (cf. detailed description in e.g., Ulrich \& Eppinger [40]). 


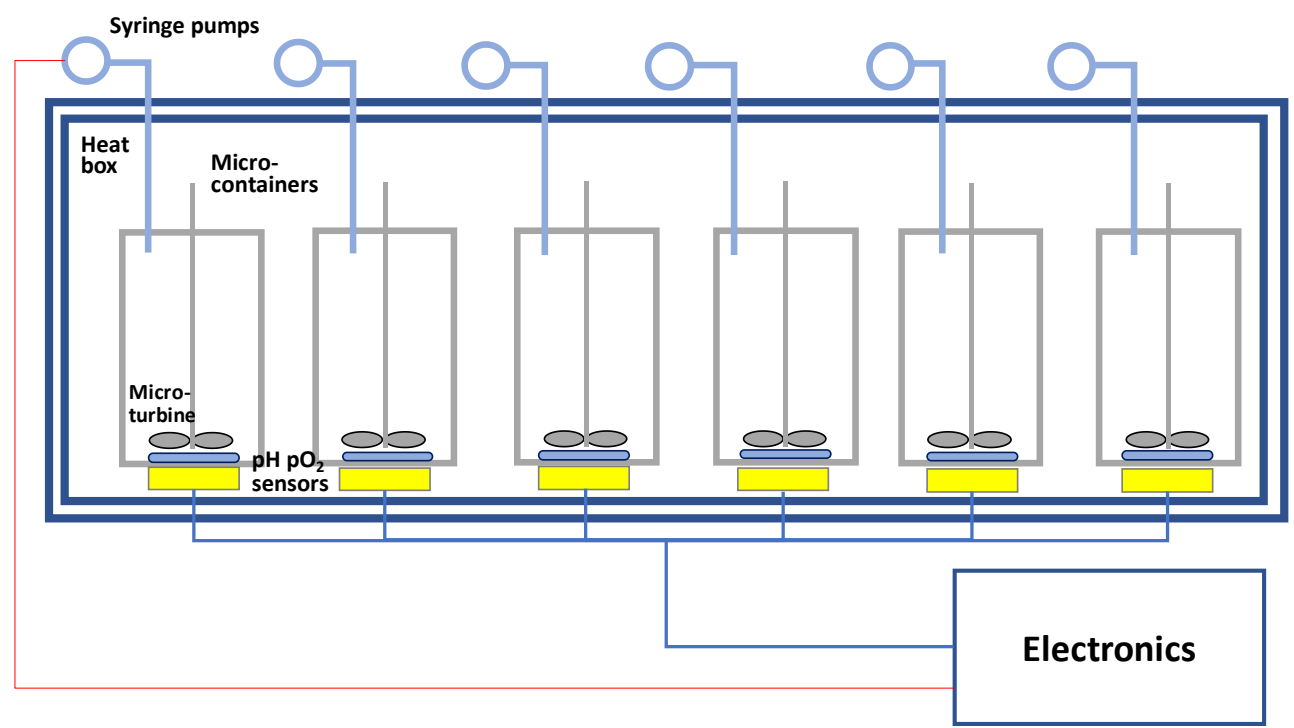

Figure 7. Blueprint of a prototype based on the ranking of components towards the need specifications. An MBR setup with six independent reactors for culture of $\mathrm{CHO}$ cells in 2-5 mL scale contained in a thermostat box. Sensors for $\mathrm{pH}$ and $\mathrm{pO}_{2}$ measure online in each MBR.

\section{A Heart-on-a-Chip Micro-Bioreactor for Assessment of Drug Safety and Efficacy}

Several designs of heart-on-a-chip (HoC) devices for assessment of clinical in vitro heart models [68-70] and for testing of toxicity and efficacy effects of drug substances on cardiac cells have been presented [71-77]. These studies have shown that the HoCs devices have the potential to facilitate and shorten drug development in the pharmaceutical industry when the HoCs can accurately reflect relevant in vivo conditions in human heart tissues related to critical drug effects. The challenge is to accomplish theses in vivo-line conditions in the HoCs. In this respect, the access to induced pluripotent stem cells (iPSC) from stratified patient groups with different genetic background makes iPSCs an attractive approach that bypasses animal testing with lesser relevance [78]. These prerequisites and ambitions have guided most recent efforts in designing $\mathrm{HoC}$ devices. Examples are studies with electrical or visual recording of the heart's beating rate with cardiac bodies [78] exposed to drug substances at varying concentrations [79].

In the example shown here, the design objective is to design a HoC prototype using commercially available, iPSC-derived cardiomyocytes [80] or cardiomyocytes developed in their own lab, e.g., at a research institute or a R\&D unit at a drug company [81]. The purpose of the design of the HoC device is to assess effects of drug candidates, either for cardiac chemotherapy or other therapies in which the heart is affected by the drug.

The cardiomyocytes in the $\mathrm{HoC}$ prototype will experience the same spatiotemporal conditions as in the in vivo heart tissues. This requires a 3-dimensional cellular microstructure inside the HoC flow-through chamber, in which other cells in the cardiac tissue shall be included as well. This could either be assemblies of co-cultured cells or assembled scaffold structure in materials such as hydrogels or other biopolymers. The perfusion around the in vitro cell assembly shall mimic the conditions in the in vivo heart tissue, which requires that the microfluidic conditions in the $\mathrm{HoC}$ are precisely designed and dimensioned.

Table 5 lists commonly expressed user needs related to drug testing on the design in line with the cellular prerequisites highlighted above, together with several others for technical, analytical, and management functions. Also, a few business-related needs are mentioned, although the conceptual design is not at this stage aiming at a market analysis of a HoC; focus is on utility and technical performance. However, manufacturing and marketing must inevitable sooner or later be addressed 
in the product development process, in which the design alternatives may play a decisive role in manufacturing, marketing, and price.

Table 5. User needs of a HoC micro-bioreactor with cardiac cells intended for compound testing.

\begin{tabular}{|c|c|c|}
\hline User Needs & Target Metrics & Specification \\
\hline \multicolumn{3}{|l|}{ Biological needs } \\
\hline Co-culture of cardiomyocytes/fibroblasts & Number other cell types than CM & $2-4$ other cell types \\
\hline Cardiomyocyte assemblies beating & Beats per minutes (bpm) & $30-100$ \\
\hline cardiac cells clustered in aggregate & Number of cells per aggregate & $500-1000$ \\
\hline $\begin{array}{l}\text { Sufficient cells in HoC to generate } \\
\text { measurable signals }\end{array}$ & Cardiac cells per HoC chamber & $500,000-1,000,000$ \\
\hline Extracellular matrix created inside MBR & Type of biomaterials & PEG, Matrigel \\
\hline \multicolumn{3}{|l|}{ Technical needs } \\
\hline $\begin{array}{l}\text { Shear force on cells corresponds in vivo of } \\
\text { liquid media (nutrients, test solutions) }\end{array}$ & Distribution of flow rates in $\mathrm{HoC} \mathrm{Psi/cm}$ & $\pm 10 \%$ \\
\hline Thermostable condition for cells in $\mathrm{HoC}$ & Temperature range inside $\mathrm{HoC}$ & $35-38^{\circ} \mathrm{C}$ \\
\hline Sampling ports for HoC effluent fluid & No. of ports and where & in: $2-3$, out: 1 \\
\hline Oxygen transfer to cardiac bodies & Dissolved oxygen tension in aggregates & above $5 \%$ \\
\hline Non-toxic fabrication materials of MBR & Type of materials & Plastics, metal \\
\hline Sterile conditions & Sterility time & 2 weeks \\
\hline \multicolumn{3}{|l|}{ Information needs } \\
\hline In situ non-destructive inspection of cells & Methods; performance & $\begin{array}{c}\text { Confocal microscopy } \\
\text { Magnification } \times 50\end{array}$ \\
\hline \multicolumn{3}{|l|}{ In situ observation of biomarkers } \\
\hline Measurement acquisition online & Methods; performance & $\mathrm{HCI}$ \\
\hline Inline monitoring of excreted substances & Methods; performance & MS, immunosensor \\
\hline \multicolumn{3}{|l|}{ Product and manufacturing requirements } \\
\hline Production cost per device $/ 10,000$ per year & EUR/unit & 2-4 EUR \\
\hline Consumable cost per assay & Range EUR/assay & 1-5 EUR \\
\hline Technician training time & Days & 3 days \\
\hline
\end{tabular}

Clearly, there are many similarities between the user needs for a HoC device shown in Table 5 and the previous MBR design for process development (Table 4). However, the requirements on the biological systems are in the $\mathrm{HoC}$ more demanding due to the complex tissue architecture of the cardiac tissue. The minimal tissue equivalent, i.e., the smallest number of cells that can recapitulate the active in vivo heart tissue unit, which must be defined and realized in the HoC chambers, is a key issue in the prototype design. Also, supportive cells, e.g., fibroblasts and nerve cells for synchronized contraction (Purkinje cells), and the structure of the myocardial extracellular matrix (ECM) should be a part of that equivalent. The interaction with the culture media plays, in this respect, a critical role in maintaining the cells' responses. The technical system functions as described in the previous MBR example remain largely unchanged for a $\mathrm{HoC}$ prototype, but are required to be extended with electrical or optical measurement functions for recording the contractions of the cell clusters. The information functions should, in the $\mathrm{HoC}$, include methods to analyze the motility of the cells or cell clusters.

These user requirements suggest a Hubka-Eder map with function systems as depicted in Figure 8. The biological system functions ( $\sum$ BioSystems) have additional subsystems for building up the heart tissue units. The other $\sum$ Systems remain much the same as in the previous example. The interactions between the $\sum$ BioSystems and the other systems will, in this application, show a higher degree of complexity due to the three cell types and the myocardial ECM. The systems' interactions with the three phases of the transformation process are in some parts similar, in others different. The preparation phase has a key role in establishing the tissue structure to generate contraction between cardiomyocytes. 
The sensors for monitoring the cell aggregates in situ are critical for generating the information that the computational procedures in the management system shall process further into interpretable data.

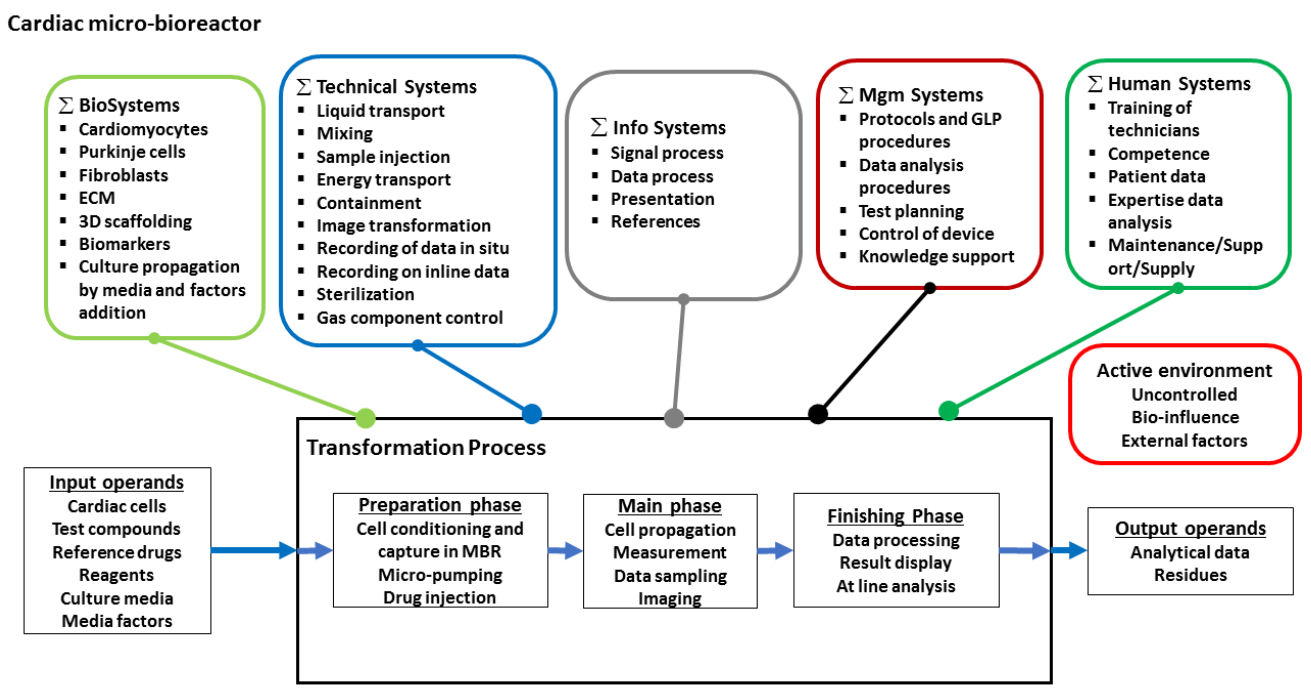

Figure 8. Hubka-Eder map showing the functional systems and subsystems that could be involved in a heart-on-a-chip MBR for purposes indicated in Table 5.

From the HE-map, the functional components related to the biological subsystems, i.e., cells and tissue functions, are identified (Figure 9A). These components can be arranged in a multitude of configurations (Figure 6B shows two possibilities of configurations). The upper configuration (I) is a design in which all cell types are confined in one body and these bodies are contained in the chip. The lower configuration (II) is a design based on parallel containment units in which cardiac bodies are kept apart. Additional configurations are, in this $\mathrm{HoC}$ application, more motivated to generate due to the extended complexity of the biological systems (not shown here) When comparing the two configurations in Figure 6 with the specification results in a ranking (with $w=1.0$ ), which favors Configuration II when using the same weights for all need attributes (Figure 6C). Interestingly, if the weights are differentiated according to the importance of the need attributes, the ranking order remains.

(A) Functional components

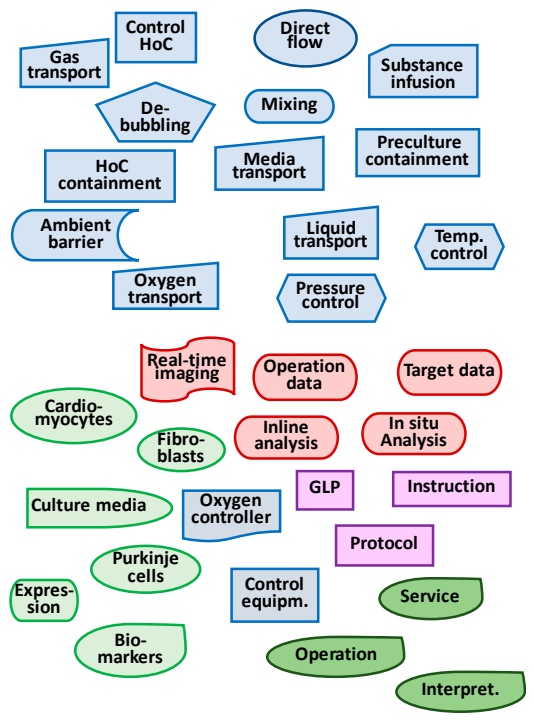

Figure 9. Cont. 
(B) Configurations

(I)

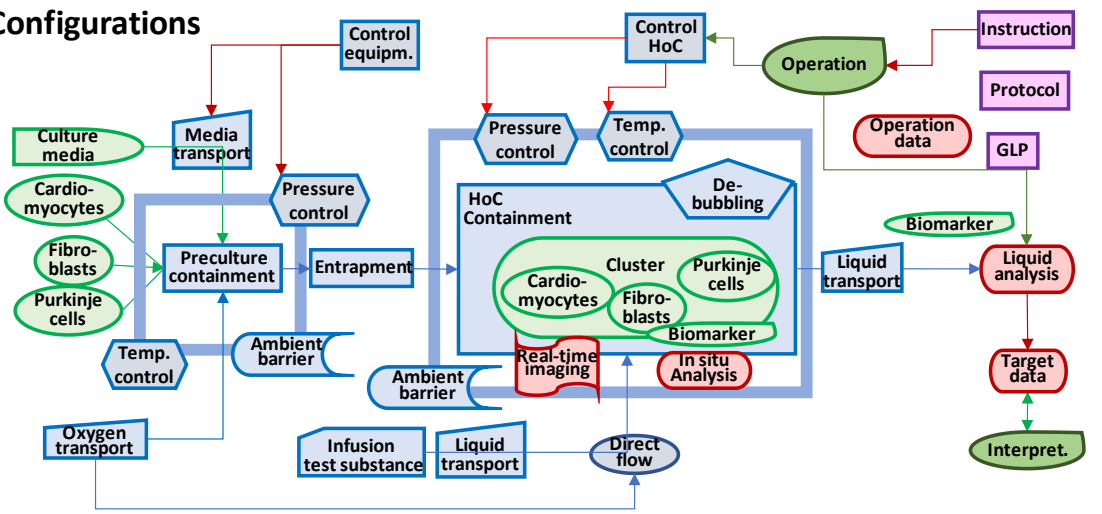

(II)

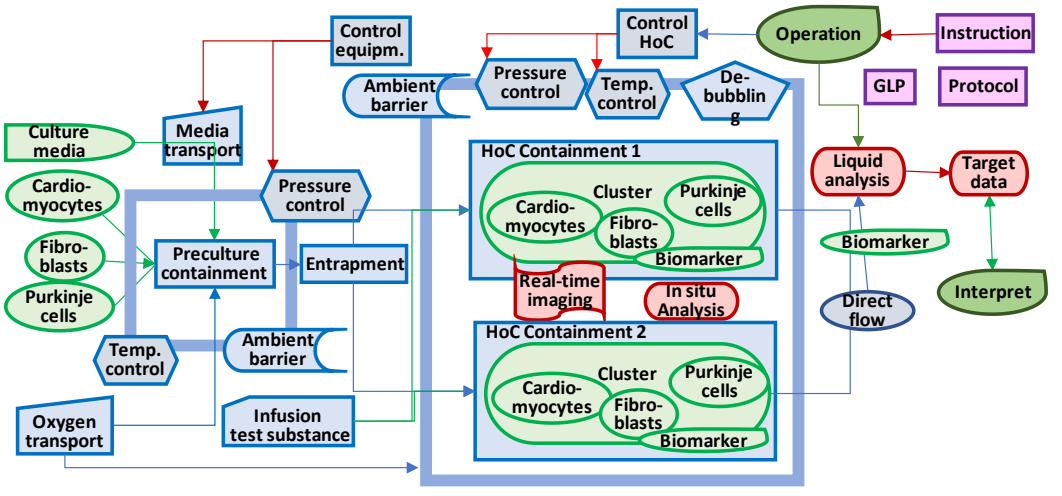

(C) Scoring of user needs (HoC for drug testing)

\begin{tabular}{|c|c|c|c|c|}
\hline & User needs & Configuration I & Configuration II & Weights \\
\hline 1 & HoC device allows co-cultures of cardiac cells & 5 & 5 & $50 \%$ \\
\hline 2 & HoC device shall remain sterile for at least 2 weeks experimentation & 5 & 4 & $50 \%$ \\
\hline 3 & Clusters of cardiac cells shall be confined in HoC device chamber & 5 & 5 & $80 \%$ \\
\hline 4 & Number of cells in HoC should correspond to in vivo heart tissue equivalent & 5 & 5 & $80 \%$ \\
\hline 5 & HoC shall allow continuous perfusion of culture media & 5 & 5 & $80 \%$ \\
\hline 6 & $\begin{array}{l}\text { HoC should have as confocal imaging optics and inline measurement possibilities } \\
\text { for monitoring beating rate and troponin release }\end{array}$ & 2 & 4 & $80 \%$ \\
\hline 7 & HoC shall be easy to scale-out for high-throughput testing to at least ten units & 3 & 5 & $100 \%$ \\
\hline 8 & HoC device shall be convenient to operate for lab technicians & 2 & 4 & $50 \%$ \\
\hline 9 & Fabrication cost of HoC shall be as low as possible & 2 & 5 & $200 \%$ \\
\hline & Score with $100 \%$ weights & 34 & 42 & \\
\hline & With weight factor as in column & 26.6 & 34.7 & \\
\hline
\end{tabular}

Figure 9. (A) Functional components required for a design of a MBR with cardiac cells based on the functional subsystems in Figure 7. (B) Two possible configurations of these functional components. (C) A comparison of the two configurations with the user needs in Table 4 in which scores are calculated for weight factors (all of which are $100 \%$ ) or as shown in last column in the table.

Next, the chosen conceptual design alternative (Configuration II) is translated into a blueprint of a heart-on-a-chip prototype in which a selection of real physical components is configured. Table S2 (Supplementary Materials) [82-87] shows the ranking of real components/devices and how these components are compared and scored versus the same need attributes that originally were identified by the users. The total scoring guides the team in the configuration of the $\mathrm{HoC}$ prototype using the components with the highest scores. Figure 10 shows an example of a blueprint of a previously published HoC device [79] with components fabricated in PDMS material using soft lithography, with a syringe pump, with an in situ microscopy, and with software analyzing the beating pattern of the cardiac cell clusters. The device is based on the guidance from the conceptual methodology. An alternative $\mathrm{HoC}$ design using commercial plastic components is described elsewhere in this issue [84]. 
(A)

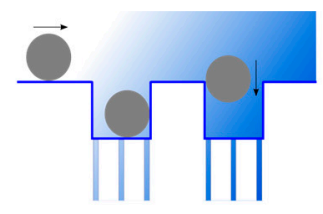

(B)

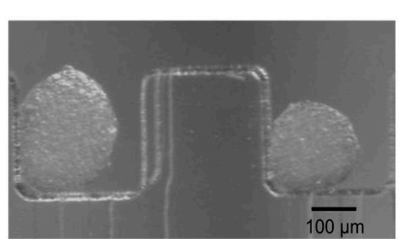

(c)

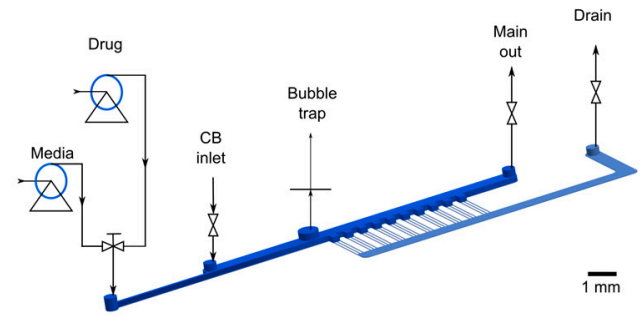

(D)

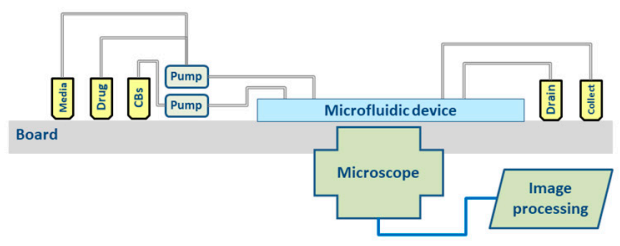

Figure 10. A blueprint of a Heart-on-Chip device designed based on the HE-map conceptual analysis in Figures 8 and 9 and the scoring of components in Table S2 (from Bergström et al. [79]). (A) Micro-wells with cardiac bodies; (B) micrograph showing two beating cardiac bodies in two wells; (C) graphic of the microfluidic device, and (D) the HoC setup.

\section{Conclusions and Outlook}

Although the complexity of the designed products varies, the same conceptual design methodology can be applied when designing MBRs and OoCs. The two MBR examples discussed in this review-(1) an MBR prototype for process development of recombinant mammalian cells for monoclonal antibody production and (2) an HoC prototype for drug testing of cardiac cells-elucidate this at two levels of complexity of biological systems.

Other OoC devices with higher degrees of complexity and multi-compartmental organization, such as brain tissues (e.g., blood-brain-barrier (BBB) chips) and the human eye (eye-on-a-chip) [88,89], exhibit design challenges beyond what is shown here for the HoC. For example, to recapitulate the membrane structure of blood capillaries in the brain or to recapitulate the functions of the multi-layer cellular assemblies of the cornea [29] and retina [90] or the blinking function of the eyelid [91] requires elaborate design efforts. Especially, the integration with the surrounding biopolymers (ECMs and membranes) forming scaffolds for realizing the 3D architecture of the organ then becomes an essential function in the design. Design work with the BBB- and eye-on-a-chip devices could benefit from the structural approach of conceptual design methodology.

One of the most important issues in the MBR design is to successfully mimic reality. For the heart-on-a-chip case, as well as other OoCs, that is about mimicking conditions in vivo of a human tissue. For the microbioreactor with a recombinant mammalian cell culture producing monoclonal antibodies, it is to mimic the conditions of a large-scale bioreactor with the same culture in the MBR. The ability of the MBR prototype to do this must be assessed experimentally by comparing data derived from the MBRs with data from the real system, i.e., the in vivo heart tissue or the large-scale bioreactor. Only when these data coincide sufficiently well, the prototype design can be considered successful. The bioanalytical possibilities to verify the correlation between the real system and the MBRs are considerably more demanding for the in vivo systems, e.g., the human heart tissue in a patient, and for some parameters this is not even possible in practice. For the large-scale bioreactor this is comparatively easy. Thus, the outcome of the design of a HoC prototype may not be satisfactorily assessed. This will most probably be the case for the mammalian cell culture MBR.

The two design examples in this review exhibit modest cellular complexity. This is the case especially for the MBR with the recombinant mammalian cells, which is a homogeneous mono-cellular culture; the cardiac chip is more complex, as it has a multi-cellular structure, but is limited to three cell types (cardiomyocytes, fibroblasts, and nerve cells). Still, the network of interactions between 
functions and real components in the design becomes significant and demanding to comprehend for the design team. This justifies the conceptual methodology with its systematic evaluation of design alternatives. The conceptual approach contributes to reducing unsuccessful prototyping of devices and facilitates the finding of favorable designs for design purposes.

Other supporting methods, such as mathematical modeling, should, however, not be neglected as useful tools to support the conceptual design. Mathematical models and dynamic simulations can be very useful, e.g., for estimating rates and dimensions in the cellular system of the organ [92]. Also, computer-aided design combined with conceptual design has proved useful in bioengineering, for example, with stem cell-derived cardiomyocytes [93]. Thus, other established engineering design methods should therefore support and complement conceptual design methods, in parallel or initiated by the conceptual directions.

Supplementary Materials: The following are available online at http:/ / www.mdpi.com/2306-5354/5/3/56/s1, Table S1: Scoring of user needs versus real components for MBR for process development Configuration I, Table S2: Scoring of user needs versus real components for Heart-on-a-Chip Configuration I.

Funding: This research received no external funding.

Acknowledgments: The author thanks Mats Björkman, Jonas Christoffersson, and Danny van Noort for valuable discussions related to this work.

Conflicts of Interest: The author declares no conflict of interest.

\section{References}

1. Bhatia, S.N.; Ingber, D.E. Microfluidic organs-on-chips. Nat. Biotechnol. 2014, 32, 760-772. [CrossRef] [PubMed]

2. Lattermann, C.; Buchs, J. Design and operation of microbioreactor systems for screening and process development. In Bioreactors: Design, Operation and Novel Applications; Mandenius, C.F., Ed.; Wiley-VCH: Weinheim, Germany, 2016; pp. 35-78, ISBN 978-3-527-33768-2.

3. Huh, D.; Matthews, B.D.; Mammoto, A.; Montoya-Zavala, M.; Hsin, H.Y.; Ingber, D.E. Reconstituting organ-level lung functions on a chip. Science 2010, 328, 1662-1668. [CrossRef] [PubMed]

4. Hegab, M.H.; ElMekawy, A.; Stakenborg, T. Review of microfluidic microbioreactor technology for high-throughput submerged microbiology cultivation. Biomicrofluidics 2013, 7, 021502. [CrossRef] [PubMed]

5. Van Duinen, V.; Treetsch, J.; Joore, J.; Vulto, P.; Hankemeier, T. Microfluidic 3D cell culture: From tools to tissue models. Curr. Opin. Biotechnol. 2015, 35, 118-126. [CrossRef] [PubMed]

6. Sun, W.; Chen, Y.-Q.; Luo, G.-A.; Zhang, M.; Zhang, H.-Y.; Wang, Y.-R.; Hu, P. Organ-on-chips and its applications. Chin. J. Anal. Chem. 2016, 44, 533-541. [CrossRef]

7. Selden, C.; Fuller, B. Role of bioreactor technology in tissue engineering for clinical use and therapeutic target design. Bioengineering 2018, 5, 32. [CrossRef] [PubMed]

8. Neuzi, P.; Giselbrecht, S.; Lange, K.; Huang, T.J.; Manz, A. Revisiting lab-on-a-chip technology for drug discovery. Nat. Rev. Drug Discov. 2012, 11, 620-632. [CrossRef] [PubMed]

9. Esch, E.W.; Bahinski, A.; Huh, D. Organs-on-chips at the frontiers of drug discovery. Nat. Rev. Drug Discov. 2015, 14, 248-260. [CrossRef] [PubMed]

10. Skardal, A.; Shupe, T.; Atala, A. Organoid-on-a-chip and body-on-a-chip systems for drug screening and disease modelling. Drug Discov. Today 2016, 21, 1399-1411. [CrossRef] [PubMed]

11. Hemmerich, J.; Noack, S.; Wiechert, W.; Oldiges, M. Microbioreactor systems for accelerated bioprocess development. Biotechnol. J. 2018, 13, 1700141. [CrossRef] [PubMed]

12. Schapper, D.; Zainal Alam, M.N.H.; Szita, N.; Eliasson Lantz, A.; Gernaey, K.V. Application of microbioreactors in fermentation process development: A review. Anal. Bioanal. Chem. 2009, 395, 679-695. [CrossRef] [PubMed]

13. Betts, J.I.; Baganz, F. Miniature bioreactors, current practice and future opportunities. Microb. Cell Fact. 2006, 5, 21. [CrossRef] [PubMed]

14. Duertz, W.A. Microtiter plates as mini-bioreactors: Miniaturization of fermentation methods. Trends Microbiol. 2007, 15, 469-475. [CrossRef] [PubMed]

15. Van Noort, D. Bioreactors on a chip. In Bioreactors: Design, Operation and Novel Applications; Mandenius, C.F., Ed.; Wiley-VCH: Weinheim, Germany, 2016; pp. 77-112, ISBN 978-3-527-33768-2. 
16. Zanzotto, A.; Boccazzi, P.; Lessard, P.; Sinskey, A.J.; Jensen, K.F. Membrane-areated microbioreactor for high-throughput bioprocessing. Biotechnol. Bioeng. 2004, 87, 243-254. [CrossRef] [PubMed]

17. Zhang, Z.; Perozziello, G.; Boccazzi, P.; Geschke, O.; Sinskey, A.J.; Jensen, K.F. Microbioreactor for bioprocess development. J. Assoc. Lab. Autom. 2007, 12, 143-151. [CrossRef]

18. Rameez, S.; Mostafa, S.S.; Miller, C.; Shukla, A.A. High-throughput miniaturized bioreactors for cell culture process, development: Reproducibility, scalability, and control. Biotechnol. Prog. 2014, 30, 718-727. [CrossRef] [PubMed]

19. ambr®250. Available online: https://www.sartorius.com/sartorius/en/EUR/products/bioreactorsfermentors/single-use/ambr-250 (accessed on 1 July 2018).

20. BioLector. Available online: https://www.m2p-labs.com/bioreactors/ (accessed on 1 July 2018).

21. Khetani, S.R.; Bhatia, S.N. Microscale culture of human liver cells for drug development. Nat. Biotechnol. 2008, 26, 120-126. [CrossRef] [PubMed]

22. Polini, A.; Prodanov, L.; Bhise, N.S.; Manoharan, V.; Dokmeci, M.R.; Khademhosseini, A. Organs on a chip a new tool for drug discovery. Exp. Opin. Drug Discov. 2014, 9, 335-352. [CrossRef] [PubMed]

23. Freyer, N.; Greuel, S.; Knöspel, F.; Gerstmann, F.; Storoch, L.; Damm, G.; Seehofer, D.; Foster Harris, J.; Iyer, R.; Schubert, F.; et al. Microscale 3D liver construct for hepatotoxicity testing in a perfused human in vitro culture platform. Bioengineering 2018, 5, 24. [CrossRef] [PubMed]

24. Wrzesinski, K.; Fey, S.J. Metabolic reprogramming and the recovery of physiological functionality in 3D cultures in micro-bioreactors. Bioengineering 2018, 5, 22. [CrossRef] [PubMed]

25. Mandenius, C.F.; Andersson, T.B.; Alves, P.M.; Batzl-Hartmann, C.; Björquist, P.; Carrondo, M.J.T.; Chesne, C.; Coecke, S.; Edsbagge, J.; Fredriksson, J.M.; et al. Towards preclinical predictive drug testing for metabolism and hepatotoxicity by in vitro models derived from human embryonic stem cells: A report on the Vitrocellomics EU-project. Altern. Lab. Anim. 2011, 39, 147-171. [PubMed]

26. Tajsoleiman, T.; Abdekhodaie, M.J.; Gernaey, K.V.; Krühne, U. Efficient computational design of a cartilage cell regeneration. Bioengineering 2018, 5, 33. [CrossRef] [PubMed]

27. Seo, J.; Huh, D. A human blinking eye-on-a-chip. In Proceedings of the 18th International Conference on Miniaturized Systems for Chemistry and Life Sciences, San Antonio, TX, USA, 26-30 October 2014.

28. Rountree, C.M.; Raghunathan, A.; Troy, J.B.; Saggere, L. Prototype chemical synapse chip for spatially patterned neurotransmitter stimulation of the retina ex vivo. Microsyst. Nanoeng. 2017, 3, 17052. [CrossRef]

29. Puleo, C.M.; McIntosh Ambrose, W.; Takezawa, T.; Elisseeff, J.; Wang, T.H. Integration and application of vitrified collagen in multi-layered microfluidic devices for corneal micro-tissue culture. Lab Chip 2009, 9, 3221-3227. [CrossRef] [PubMed]

30. Materne, E.M.; Maschmeyer, I.; Lorenz, A.K.; Horland, R.; Schimek, K.M.; Busek, M.; Sonntag, F.; Lauster, R.; Marx, U. The multi-organ chip-A microfluidic platform for long-term multi-tissue coculture. J. Visual. Exp. 2015, 98, e52526. [CrossRef] [PubMed]

31. Bauer, S.; Huldt, C.W.; Kanebratt, K.P.; Durieux, I.; Gunne, D.; Andersson, S.; Ewart, L.; Haynes, W.G.; Maschmeyer, I.; Winter, A.; et al. Functional coupling of human pancreatic islets and liver spheroids on-a-chip: Towards a novel human ex vivo type 2 diabetes model. Sci. Rep. 2017, 7, 14620. [CrossRef] [PubMed]

32. Toh, Y.-C.; Raja, A.; Yu, H.; van Noort, D. A 3D microfluidic model to recapitulate cancer cell migration and invasion. Bioengineering 2018, 5, 29. [CrossRef] [PubMed]

33. Kühlbach, C.; da Luz, S.; Mueller, M.M.; Baganz, F.; Volker, C.; Hass, V.C. A microfluidic system for investigation of tumor cell extravasation. Bioengineering 2018, 5, 40. [CrossRef] [PubMed]

34. Gernaey, K.V.; Baganz, F.; Franco-Lara, E.; Kensy, F.; Krühne, U.; Luebberstedt, M.; Marx, U.; Palmquist, E.; Schmid, A.; Schubert, F.; et al. Monitoring and control of microbioreactors: An expert opinion on development needs. Biotechnol. J. 2012, 7, 1308-1314. [CrossRef] [PubMed]

35. Maoz, B.M.; Herland, A.; Henry, O.Y.F.; Leineweber, W.D.; Yadid, M.; Doyle, J.; Mannix, R.; Kujala, W.D.; FitzGerald, E.A.; Parker, K.K.; et al. Organs-on-Chips with combined multi-electrode array and transepithelial electrical resistance measurement capabilities. Lab Chip 2017, 17, 2294-2302. [CrossRef] [PubMed]

36. Zhang, Y.S.; Aleman, J.; Shin, S.R.; Kilic, T.; Kim, D.; Shaegh, S.A.; Massa, S.; Riahi, R.; Chae, S.; Hu, N.; et al. Multi-sensor integrated organs-on-chips platform for automated and continual in situ monitoring of organoid behaviors. Proc. Natl. Acad. Sci. USA 2017, 114, E2293-E2302. [CrossRef] [PubMed] 
37. Fernandez, A.C.; Halder, J.M.; Nestl, B.M.; Hauer, B.; Gernaey, K.V.; Krühne, U. Biocatalyst screening with a twist: Application of oxygen sensors integrated in microchannels for screening whole cell biocatalyst variants. Bioengineering 2018, 5, 30. [CrossRef] [PubMed]

38. Hubka, V.; Eder, E.W. Design Science: Introduction to the Needs, Scope and Organization of Engineering Design Knowledge, 1st ed.; Springer: Berlin, Germany, 1996.

39. Pahl, G.; Beitz, W.; Feldhusen, J.; Grote, K. Engineering Design: A Systematic Approach, 3rd ed.; Springer: Berlin, Germany, 2007.

40. Ulrich, K.T.; Eppinger, S.D. Product Design and Development, 3rd ed.; McGraw-Hill: New York, NY, USA, 2007.

41. Derelöv, M.; Jonas Detterfelt, J.; Mats Björkman, M.; Mandenius, C.-F. Engineering design methodology for bio-mechatronic products. Biotechnol. Prog. 2008, 24, 232-244. [CrossRef] [PubMed]

42. Mandenius, C.-F.; Björkman, M. Mechatronics design principles for biotechnology product development. Trends Biotechnol. 2010, 28, 230-236. [CrossRef] [PubMed]

43. Mandenius, C.F.; Björkman, M. Scale-up of bioreactors using biomechantronic design methodology. Biotechnol. J. 2012, 7, 1026-1039. [CrossRef] [PubMed]

44. Mandenius, C.-F. Biomechatronics for designing bioprocess monitoring and control systems: Application to stem cell production. J. Biotechnol. 2012, 162, 430-440. [CrossRef] [PubMed]

45. Mandenius, C.F. Design of monitoring and sensor systems for bioprocesses using biomechatronic principles. Chem. Eng. Technol. 2012, 35, 1412-1420. [CrossRef]

46. Gerlach, I.; Hass, V.C.; Mandenius, C.F. Conceptual design of an operating training simulator for a bio-ethanol plant. Processes 2015, 3, 664-683. [CrossRef]

47. Christoffersson, J.; van Noort, D.; Mandenius, C.-F. Developing organ-on-a-chip concepts using bio-mechatronic design methodology. Biofabrication 2017, 9, 025023. [CrossRef] [PubMed]

48. Mandenius, C.-F.; Björkman, M. Biomechatronic Design in Biotechnology-A Methodology for Development of Biotechnological Products, 1st ed.; Wiley \& Sons: New York, NY, USA, 2011.

49. Yetisen, A.K.; Volpatti, L.R.; Coskun, A.F.; Cho, S.; Kamrani, E.; Butt, H.; Khademhosseinidfgh, A.; Yun, S.H. Entrepreneurship. Lab Chip 2015, 15, 3638-3660. [CrossRef] [PubMed]

50. Junaid, A.; Mashaghi, A.; Henkemeier, T.; Vulto, P. An end-user perspective on Organ-on-a-chip: Assays and usability aspects. Curr. Opin. Biomed. Eng. 2017, 1, 15-22. [CrossRef]

51. Nienow, A.W.; Rielly, C.D.; Brosnan, K.; Bargh, N.; Lee, K.; Coopman, K.; Hewitt, C.J. The physical characterisation of a microscale parallel bioreactor platform with an industrial $\mathrm{CHO}$ cell line expressing an IgG4. Biochem. Eng. J. 2013, 76, 25-36. [CrossRef]

52. Janakiraman, V.; Kwiatkowski, C.; Kshirsagar, R.; Ryll, T.; Huang, Y.M. Application of high-throughput mini-bioreactor system for systematic scale-down modeling, process characterization, and control strategy development. Biotechnol. Prog. 2015, 31, 623-632. [CrossRef] [PubMed]

53. Hsu, W.T.; Aulakh, R.P.S.; Traul, D.L.; Yuk, I.H. Advanced microscale bioreactor system: A representative scale-down model for bench-top bioreactors. Cytotechnology 2012, 64, 667-678. [CrossRef] [PubMed]

54. Zhang, Z.; Boccazzi, P.; Choi, H.G.; Perozziello, G.; Sinskey, A.J.; Jensen, K.F. Microchemostat, a microbial continuous culture in a polymer-based, instrumented microbioreactor. Lab Chip 2006, 6, 906-913. [CrossRef] [PubMed]

55. Wurm, F.M. Production of recombinant protein therapeutics in cultivated mammalian cells. Nat. Biotechnol. 2004, 22, 1393-1398. [CrossRef] [PubMed]

56. Huang, Y.M.; Hu, W.W.; Rustandi, E.; Chang, K.; Yusuf-Makagianser, H.; Ryll, T. Maximizing productivity of $\mathrm{CHO}$ cell-based fed-batch culture using chemically defined media conditions and typical manufacturing equipment. Biotechnol. Prog. 2010, 26, 1400-1410. [CrossRef] [PubMed]

57. Griffiths, J.B. Mammalian cell culture reactors, scale-up. In Encyclopedia of Industrial Biotechnology; Flickinger, M.C., Ed.; John Wiley \& Sons: Hoboken, NJ, USA, 2010; Volume 5, pp. 3228-3241.

58. Nienow, A.W. Reactor engineering in large scale animal cell culture. Cytotechnology 2006, 50, 9-33. [CrossRef] [PubMed]

59. Becker, E.; Florin, L.; Pfizenmaier, K.; Kaufmann, H. An XBP-1 dependent bottle-neck in production of IgG subtype antibodies in chemically defined serum-free Chinese hamster ovary $(\mathrm{CHO})$ fed-batch processes. J. Biotechnol. 2008, 135, 217-223. [CrossRef] [PubMed] 
60. Xu, P.; Clark, C.; Ryder, T.; Sparks, C.; Zhou, J.; Wang, M.; Russell, R.; Scott, C. Characterization of TAP Ambr 250 disposable bioreactors, as a reliable scale-down model for biologics process development. Biotechnol. Prog. 2017, 33, 478-789. [CrossRef] [PubMed]

61. Kommenhoek, E.E.; van Leeuwen, M.; Gardeniers, H.; van Gulik, W.M.; van den Berg, A.; Li, X.; Ottens, M.; van der Wielen, L.A.M.; Heijnen, J.J. Lab-scale fermentation tests of microchip with integrated electrochemical sensors for $\mathrm{pH}$, temperature, dissolved oxygen and viable biomass concentration. Biotechnol. Bioeng. 2008, 99, 884-892. [CrossRef] [PubMed]

62. Thuenauer, R.; Juhasz, K.; Mayr, R.; Fruhwirth, T.; Lipp, A.M.; Balogi, Z.; Sonnleitner, A. A PDMS-based biochip with integrated sub-micrometre position control for TIRF microscopy of the apical cell membrane. Lab Chip 2011, 11, 3064-3071. [CrossRef] [PubMed]

63. Mandenius, C.F. Bioreactors: Design, Operation and Novel Applications; Mandenius, C.F., Ed.; Wiley-VCH: Weinheim, Germany, 2016; ISBN 978-3-527-33768-2.

64. LabSmith. Available online: http:/ / labsmith.com/ (accessed on 1 July 2018).

65. Bengtsson, K.; Christoffersson, J.; Mandenius, C.F.; Robinson, N.D. A clip-on electroosmotic pump for oscillating flow in microfluidic cell culture devices. Microfluid. Nanofluid. 2018, 22, 27. [CrossRef]

66. Joeris, K.; Frerichs, J.G.; Konstantinov, K.; Scheper, T. In-situ microscopy: Online process monitoring of mammalian cell cultures. Cytotechnology 2002, 38, 129-134. [CrossRef] [PubMed]

67. Noll, T.; Biselli, M. Dielectric spectroscopy in the cultivation of suspended and immobilized hybridoma cells. J. Biotechnol. 1998, 63, 187-198. [CrossRef]

68. Tanaka, Y.; Sato, K.; Shimizu, T.; Yamoto, M.; Okano, T.; Kitamori, T. A micro-spherical heart pump powered by cultured cardiomyocytes. Lab Chip 2007, 7, 207-212. [CrossRef] [PubMed]

69. Grosberg, A.; Alford, P.W.; McCain, M.L.; Parker, K.K. Ensembles of engineered cardiac tissues for physiological and pharmacological study: Heart on a chip. Lab Chip 2011, 11, 4165-4173. [CrossRef] [PubMed]

70. Martewicz, S.; Michielin, F.; Serena, E.; Zambon, A.; Mongillo, M.; Elvassore, N. Reversible alteration of calcium dynamics in cardiomyocytes during acute hypoxia transient in a microfluidic platform. Integr. Biol. 2012, 4, 153-164. [CrossRef] [PubMed]

71. Agarwal, A.; Goss, J.A.; Cho, A.; McCain, M.L.; Parker, K.K. Microfluidic heart on a chip for higher throughput pharmacological studies. Lab Chip 2013, 13, 3599-3608. [CrossRef] [PubMed]

72. Annabi, N.; Selimovic, S.; Acevedo Cox, J.P.; Ribas, J.; Afshar Bakooshli, M.; Heintze, D.; Weiss, A.S.; Cropek, D.; Khademhosseini, A. Hydrogel-coated microfluidic channels for cardiomyocyte culture. Lab Chip 2013, 13, 3569-3577. [CrossRef] [PubMed]

73. Ren, L.; Liu, W.; Wang, Y.; Wang, J.C.; Tu, Q.; Xu, J.; Liu, R.; Shen, S.F.; Wang, J. Investigation of Hypoxia-Induced Myocardial Injury Dynamics in a Tissue Interface Mimicking Microfluidic Device. Anal. Chem. 2013, 85, 235-244. [CrossRef] [PubMed]

74. Kaneko, T.; Nomura, F.; Hamada, T.; Abe, Y.; Takamori, H.; Sakakura, T.; Takasuna, K.; Sanbuissho, A.; Hyllner, J.; Sartipy, P.; et al. On-chip in vitro cell-network pre-clinical cardiac toxicity using spatiotemporal human cardiomyocyte measurement on a chip. Sci Rep. 2014, 4, 4670. [CrossRef] [PubMed]

75. Marsano, A.; Conficconi, C.; Lemme, M.; Occhetta, P.; Gaudiello, E.; Votta, E.; Cerino, G.; Redaelli, A.; Rasponi, M. Beating heart on a chip: A novel microfluidic platform to generate functional 3D cardiac microtissues. Lab Chip 2016, 16, 599-610. [CrossRef] [PubMed]

76. Zhang, Y.S.; Arneri, A.; Bersini, S.; Shin, S.R.; Zhu, K.; Goli-Malekabadi, Z.; Aleman, J.; Colosi, C.; Busignani, F.; Dell'Erba, V.; et al. Bioprinting 3D microfibrous scaffolds for engineering endothelialized myocardium and heart-on-a-chip. Biomaterials 2016, 110, 45-59. [CrossRef] [PubMed]

77. Zweigerdt, R.; Gruh, I.; Martin, U. Your heart on a chip: IPSC-based modeling of Barth-syndrome-associated cardiomyopathy. Cell Stem Cell 2014, 15, 9-11. [CrossRef] [PubMed]

78. Jastrzebska, E.; Tomecka, E.; Jesion, I. Heart-on-a-chip based on stem cell biology. Biosens. Bioelectron. 2016, 75, 67-81. [CrossRef] [PubMed]

79. Bergström, G.; Christoffersson, J.; Zweigerdt, R.; Schwanke, K.; Mandenius, C.F. Stem cell derived cardiac bodies in a microfluidic device for toxicity testing by beating frequency imaging. Lab Chip 2015, 15, 3242-3249. [CrossRef] [PubMed]

80. iCell@Cardiomyocytes. Available online: https://cellulardynamics.com/products-services/icell-products / icell-cardiomyocytes / (accessed on 1 July 2018). 
81. Morrison, M.; Klein, C.; Clemann, N.; Collier, D.A.; Hardy, J.; Heißerer, B.; Cader, M.Z.; Graf, M.; Kaye, J. StemBANCC: Governing access to material and data in a large stem cell research consortium. Stem Cell Rev. Rep. 2015, 11, 681-687. [CrossRef] [PubMed]

82. Mandenius, C.F.; Steel, D.; Noor, F.; Meyer, T.; Heinzle, E.; Asp, J.; Arain, S.; Kraushaar, U.; Bremer, S.; Class, R.; et al. Cardiotoxicity testing using pluripotent stem cell derived human cardiomyocytes and state-of-the-art bioanalytics: A review. J. Appl. Toxicol. 2011, 31, 191-205. [CrossRef] [PubMed]

83. Andersson, H.; Steel, D.; Asp, J.; Dahlenborg, K.; Jonsson, M.; Kågedal, B.; Jeppsson, A.; Lindahl, A.; Sartipy, P.; Mandenius, C.-F. Assaying cardiac biomarkers for toxicity testing using biosensing and cardiomyocytes derived from human embryonic stem cells. J. Biotechnol. 2010, 150, 175-181. [CrossRef] [PubMed]

84. Christoffersson, J.; Meier, F.; Kempf, H.; Schwanke, K.; Coffee, M.; Beilmann, M.; Zweigerdt, R.; Mandenius, C.F. A cardiac cell outgrowth assay for evaluating drug compounds using a cardiac spheroid-ona-chip device. Bioengineering 2018, 5, 36. [CrossRef] [PubMed]

85. Bergström, G.; Nilsson, K.; Robinson, N.; Mandenius, C.F. Macroporous microcarriers for introducing cells in a microfluidic chip. Lab Chip 2014, 14, 3502-3504. [CrossRef] [PubMed]

86. PerkinElmer. Available online: www.perkinelmer.com/HighContent/Screening (accessed on 1 July 2018).

87. Mimetas. Available online: https://mimetas.com/page/products (accessed on 1 July 2018).

88. Estlack, Z.; Bennet, D.; Reid, T.; Kim, J. Microengineered biomimetic ocular models for ophthalmological drug development. Lab Chip 2017, 17, 1539-1551. [CrossRef] [PubMed]

89. Chan, Y.K.; Sy, K.H.; Wong, C.Y.; Man, P.K.; Wong, D.; Shum, H.C. In vitro modeling of emulsification of silicone oil as intraocular tamponade using micro-engineered Eye-on-a-Chip. Investig. Ophthalmol. Vis. Sci. 2015, 56, 3314-3319. [CrossRef] [PubMed]

90. Dodson, K.H.; Echevarria, F.D.; Li, D.; Sappington, R.M.; Edd, J.F. Retina-on-a-chip: A microfluidic platform for point access signaling studies. Biomed. Microdevices 2015, 17, 114. [CrossRef] [PubMed]

91. Seo, J.; Byun, W.Y.; Frank, A.; Massaro-Giordano, M.; Lee, V.; Bunya, V.Y.; Huh, D. Human blinking eye-on-a-chip. Investig. Ophthalmol. Vis. Sci. 2016, 57, 3872.

92. Grause, S.; Hsu, K.H.; Shafor, C.; Dixon, P.; Powell, K.C.; Chauhan, A. Mechanistic modelling of ophthalmic drug delivery to the anterior chamber by eye drops and contact lenses. Adv. Colloid Interface Sci. 2016, 233, 139-154.

93. Darkins, C.L.; Mandenius, C.F. Design of large-scale manufacturing of induced pluripotent stem cell derived cardiomyocytes. Chem. Eng. Res. Des. 2014, 92, 1142-1152. [CrossRef] 